\title{
Crustal melting and recycling: geochronology and sources of Variscan syn-kinematic anatectic granitoids of the Tormes Dome (Central Iberian Zone). A U-Pb LA-ICP-MS study
}

\author{
F. J. López-Moro ${ }^{1}$ M. López-Plaza ${ }^{1}$ - G. Gutiérrez-Alonso ${ }^{1,2}$ (1) \\ J. Fernández-Suárez ${ }^{3}$ A. López-Carmona ${ }^{1,2} \cdot$ M. Hofmann ${ }^{4} \cdot$ R. L. Romer ${ }^{5}$
}

Received: 27 February 2017 / Accepted: 10 April 2017 / Published online: 28 April 2017

(C) Springer-Verlag Berlin Heidelberg 2017

\begin{abstract}
In this study, we report U-Pb Laser Ablation ICPMS zircon and ID-TIMS monazite ages for peraluminous granitoid plutons (biotite \pm muscovite \pm cordierite \pm sillimanite) in the Tormes Dome, one of the gneiss-cored domes located in the Central Iberian Zone of the Variscan belt of northern Spain. Textural domains in zircon, interpreted to represent the magmatic crystallization of the granitoids (and one monazite fraction in the Ledesma pluton) yielded ages around $320 \mathrm{Ma}$, in agreement with other geochronological studies in the region. This age is interpreted to date the timing of decompression crustal melting driven by the extensional collapse of the orogenic belt in this domain of the Variscan chain of western Europe. In addition, there are several populations of inherited (xenocrystic) zircon: (1) Carboniferous zircon crystals (ca. $345 \mathrm{Ma}$ ) as well as one of the monazite fractions in the coarse-grained facies of the
\end{abstract}

Electronic supplementary material The online version of this article (doi:10.1007/s00531-017-1483-8) contains supplementary material, which is available to authorized users.

G. Gutiérrez-Alonso

gabi@usal.es

1 Departamento de Geología, University of Salamanca, 37008 Salamanca, Spain

2 Geology and Geography Department, Tomsk State University, Lenin Street 36, Tomsk 634050, Russian Federation

3 Departamento de Petrología y Geoquímica, Universidad Complutense and IGEO, CSIC, 28040 Madrid, Spain

4 Senckenberg Naturhistorische Sammlungen Dresden, Museum für Mineralogie und Geologie, Koenigsbruecker Landstr. 159, 01109 Dresden, Germany

5 Deutsches GeoForschungsZentrum (GFZ), Telegrafenberg, 14473 Potsdam, Germany
Ledesma pluton that also yielded an age of ca. 343 Ma. (2) Devonian-Silurian zircon xenocrysts with scattered ages between ca. 390 and 432 Ma. (3) Middle Cambrian-Ordovician (ca. 450-511 Ma). (4) Ediacaran-Cryogenian zircon ages (ca. 540-840 Ma). (5) Mesoproterozoic to Archaean zircon (900-2700 Ma). The abundance of Carboniferousinherited zircon shows that crustal recycling/cannibalization may often happen at a fast pace in orogenic scenarios with only short lapses of quiescence. In our case study, it seems plausible that a "crustal layer" of ca. 340 Ma granitoids/ migmatites was recycled, partially or totally, only 15-20 My after its emplacement.

Keywords U-Pb geochronology · Laser ablation · Iberia · Variscan $\cdot$ Anatectic granitoids

\section{Introduction}

The late-orogenic extension of the hinterland of collisional belts leads to the development of large gneiss-cored domes that typically undergo long-lived magmatic activity including intense migmatization and concomitant generation of decompressional crustal melts (i.e., Sawyer 1994, 1999; Brown 1994, 2001; Vanderhaeghe and Teyssier 2001; Vanderhaeghe 2004). Several realms of the European Variscan Belt (Fig. 1) exhibit the superposition of granitoid suites that record the complete magmatic history of the orogen, including late-orogenic extension-related peraluminous anatectic domains (Martínez and Rolet 1988; Rossi and Cocherie 1991; Timmerman 2008; Faure et al. 2009a, b; Lardeaux et al. 2014; Tabaud et al. 2015). In NW Iberia, there are several gneiss-cored domes: Lugo (Arenas and Martínez Catalán 2003; Reche et al. 1998; Alcock et al. 2009), Sanabria (Díez Montes 2007), Tormes (Martínez 
Fig. 1 Permian reconstruction of the West European Variscan Belt (according to Ballèvre et al. 2014, modified by Fernández-Lozano et al. 2016). Red star indicates the location of the study area. CZ Cantabrian Zone, WALZ West Asturian-Leonese Zone, CIZ Central Iberian Zone, $O M Z$ Ossa-Morena Zone, SPZ South Portuguese Zone

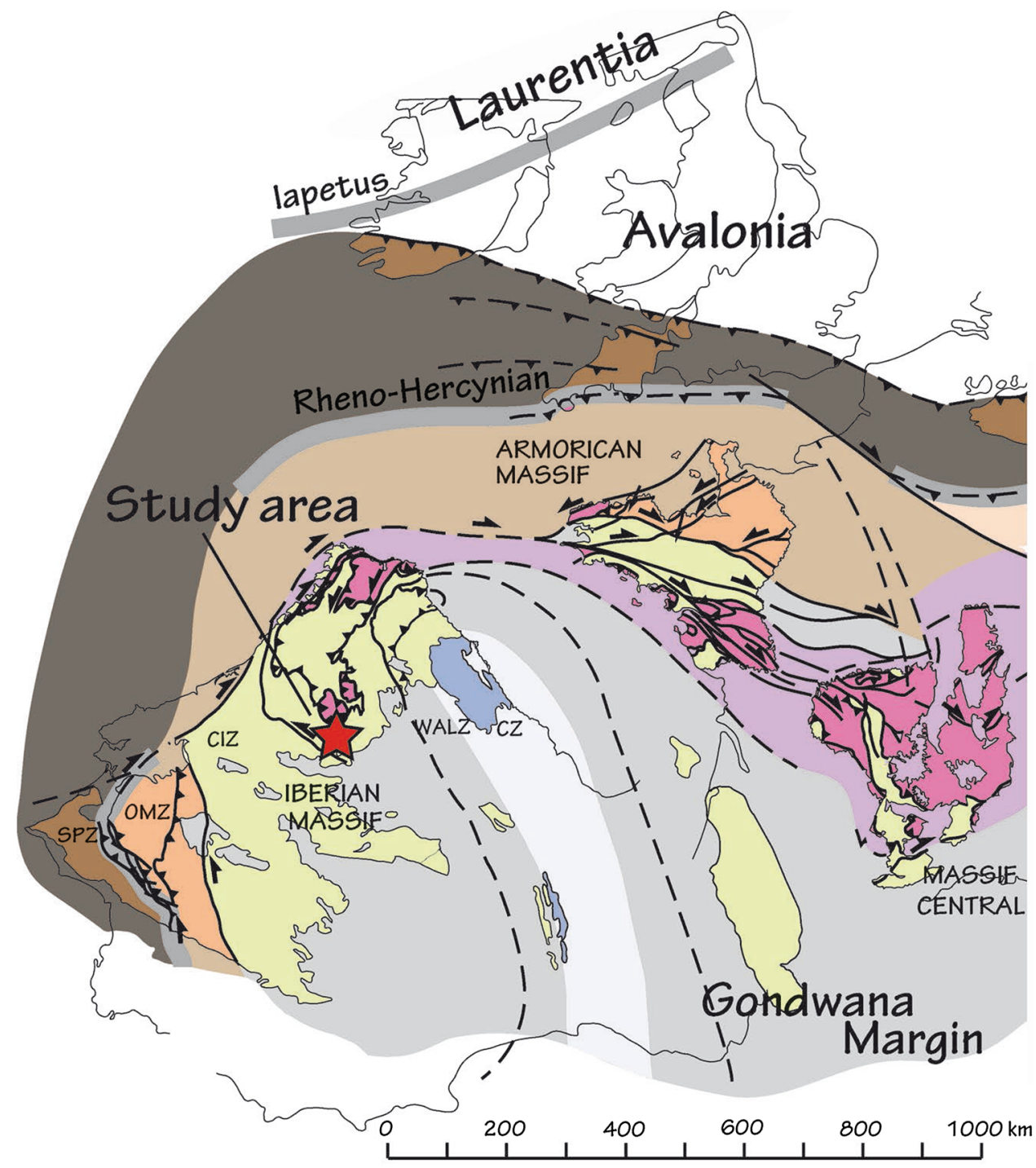

OUTCROPPING / COVERED

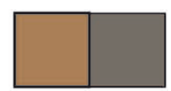

External thrust belt and foredeep basin



Allochthonous terranes with oceanic-like and high-P rocks

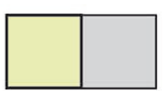

Gondwanan zones with Early Ordovician magmatism

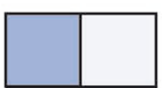

Variscan foreland thrust belt (CZ)

Gondwanan zones with strong Cadomian imprint
Oceanic suture
1977; López-Plaza and Gonzalo 1993; Martínez et al. 1988; López-Plaza et al. 1999; Escuder Viruete et al. 1997, 2000) (Fig. 2), Guadarrama (Barbero and Villaseca 2000), Somosierra (Rubio Pascual et al. 2013), Toledo (Barbero 1995; Barbero et al. 1995; Bea et al. 2006a; Castiñeiras et al. 2008), Padrón (Díez Fernández et al. 2012), Peares, and Celanova. All these domes include a structurally lower unit (core) made up of meta-igneous and meta-sedimentary migmatites that constitute the wall rocks to syn-extensional crustal leucogranitoids, whose source is debated (Bea et al.
2003; Fernández-Suárez et al. 2011), and an upper unit, limited by $\mathrm{km}$ scale extensional shear zones, with peraluminous syn-kinematic granitoids that also intrude the lower grade metamorphic rocks. For comprehensive reviews on the origin and evolution of these domes, see Martínez-Catalán et al. (2014) and Alcock et al. (2015).

The cost and time efficient U-Pb Laser ablation ICP-MS technique allows for a statistically robust characterization of the zircon age spectrum of granitoid rocks, determining the age of the magmatic event and characterizing the main 


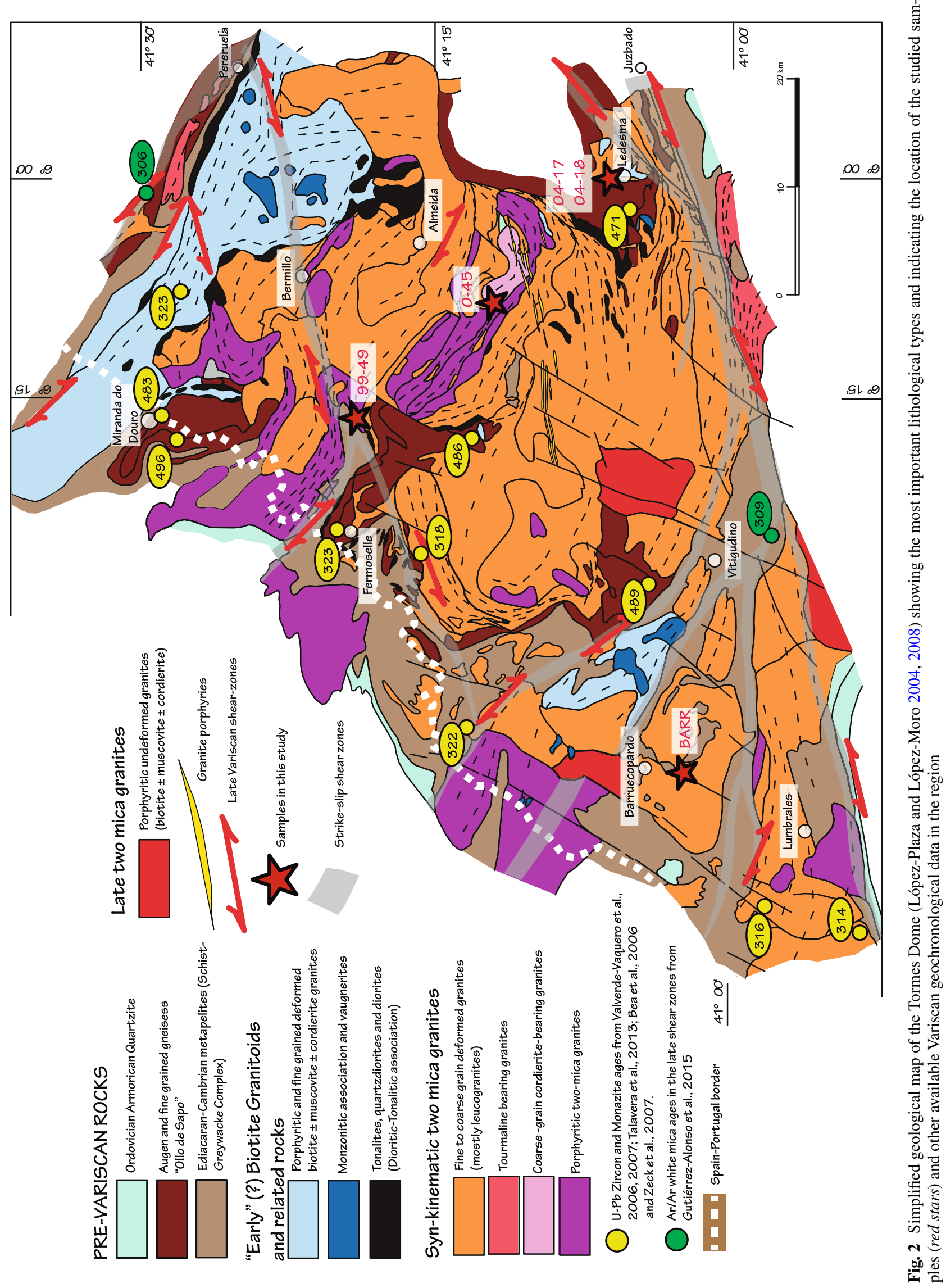


sources (zircon-bearing rocks) involved in crustal melting. In high-grade domains, with a prolonged history of recurrent migmatization, magmatic zircon may not only be related to the emplacement of the granite, but also the age spectrum of zircon from such rocks may contain several generations of magmatic zircon and inherited zircon from the source and/or assimilated wall rocks. This study shows that crustal recycling/cannibalization may often happen at a fast pace in orogenic scenarios with only short lapses of quiescence; in our case, it seems plausible that a "crustal layer" of ca. $340 \mathrm{Ma}$ granitoids/migmatites was recycled, partially or totally, only 15-20 My after its emplacement.

The present study focuses on the crystallization history of crustal granitoids in the Tormes Dome and the source rocks involved in their generation. The results obtained herein constrain the emplacement age of the studied synkinematic granitoids to ca. $320 \mathrm{My}$ ago and suggest that the main sources of magma correspond to different rock types which can be identified in their surroundings (Ediacaran and Ordovician), together with other sources (Devonian and Early Carboniferous) whose nature and origin must be further tested.

\section{Geological setting}

The Iberian Massif represents a large area of Palaeozoic and Ediacaran rocks in western Iberia (Fig. 1) and is part of the Variscan orogen of Western Europe. The Iberian Massif includes Proterozoic Gondwanan rocks with north African affinity, which form the basement for Ediacaran-Early Cambrian subduction-related and Lower Palaeozoic passive margin sequences (e.g., Rodríguez-Alonso et al. 2004; Murphy et al. 2008; Fernández-Suárez et al. 2014; RubioOrdóñez et al. 2015). In the late Devonian and Carboniferous, collision of the passive margin of Gondwana (acting as the lower plate) with Laurussia (upper plate) resulted in the Variscan orogen and ultimately the amalgamation of Pangea (e.g., Matte 1986, 2001; Murphy et al. 2009; Kroner and Romer 2013; Kroner et al. 2016). A sequence of magmatic events recorded in rocks of the Variscan orogen of Iberia can be summarized as follows: (1) A subductionrelated Cadomian (ca. $600 \mathrm{Ma}$ ) magmatic event dominated by I-type granitoids and volcanic rocks (Fernández-Suárez et al. 1998; Rubio-Ordóñez et al. 2015). This event is scarcely represented in NW Iberia; (2) a voluminous extension-related late Cambrian to early Ordovician magmatic event (ca. 490-470 Ma) generally interpreted to be linked to the opening of the Rheic Ocean (Murphy et al. 2006; Bea et al. 2006b; Montero et al. 2007; Díez Montes et al. 2010; Valverde-Vaquero and Dunning 2000; Talavera et al. 2013); (3) carboniferous syn-orogenic (Variscan) magmatism that began at ca. 350-340 Ma in the hinterland of the orogen (Gallastegui 2005) and ended at ca. 320-315 Ma (e.g., Valle Aguado et al. 2005; Dias et al. 1998; Fernández-Suárez et al. 2000); (4) post-orogenic magmatism that peaked at ca. 310-295 Ma when voluminous granitoids and some mafic rocks with their extrusive equivalents were emplaced and erupted in both the internal and external zones of the orogen (Fernández-Suárez et al. 2000, 2011; Bea et al. 2006a; Orejana et al. 2009; Gutiérrez-Alonso et al. 2011). This post-orogenic magmatism is observed throughout the entire Variscan belt (e.g., Kroner and Romer 2013).

\section{Geology of the Tormes Dome}

Gneiss-cored domes within the Central Iberian Zone (Fig. 1), one of the paleogeographic domains of the Iberian Massif, include the Tormes Dome (TD) (Fig. 2) and the Sanabria and Somosierra domes. The Central Iberian Zone is characterized by abundant magmatic rocks, some of which crop out in the core of the structural gneiss-cored domes, forming characteristic high-grade, commonly migmatized, plutono-metamorphic complexes (Martínez et al. 1988). The present-day geometry of the TD dome resulted from the superposition of (1) extensional Variscan structures that controlled the location of zones of extensive partial melting and multiple granite intrusion and (2) post-Variscan strike-slip shear zones (Fig. 2). The Variscan magmatic rocks of the TD include (1) calc-alkaline (and K-rich) granitoids and associated monzonitic rocks of I-type affinity (López-Moro and López-Plaza 2004), which traditionally have been referred to as "Older Granodiorites" or "Granodiorite Suite" (Capdevila et al. 1973; Castro et al. 2002), and (2) S-type peraluminous leucogranites (LópezPlaza et al. 2008; López-Moro et al. 2012), which are abundant throughout the NW Iberian Massif and are known as "Older two-mica Granites" or "Peraluminous Suite" (Capdevila et al. 1973; Castro et al. 2002). Calc-alkaline and $\mathrm{K}$-rich granitoids are made up of fine- to medium-grained biotite \pm muscovite granites, porphyritic biotite granites, and porphyritic biotite \pm muscovite granites (Fig. 2). S-type peraluminous leucogranites consist of porphyritic two-mica \pm sillimanite granites and equigranular granites. The latter are composed of two-mica granites (coarsegrained, medium-grained, and fine-grained granites), tourmaline-bearing granites (mainly coarse-grained granites), garnet-bearing granites (medium- to very coarse-grained), and cordierite granites (medium- to very coarse-grained).

The metamorphic and igneous rocks in the TD have been divided into a Lower Unit and an Upper Unit (Escuder Viruete et al. 1994) separated by an initially shallow dipping extensional ductile detachment with top to the SE displacement. The Lower Unit includes migmatized felsic gneisses and migmatized Neoproterozoic-Lower Cambrian 
sandstones and pelites, partially metamorphosed into garnet-cordierite-biotite-sillimanite paragneisses (Gil Ibarguchi and Martínez 1982). The felsic gneisses comprise garnet-bearing, fine-grained gneisses, and Early Ordovician augen gneisses (Bea et al. 2006b; Talavera et al. 2013). The Upper Unit represents the highest structural level of the dome and consists of a monotonous sequence of Lower Cambrian slates and schists in lower grade metamorphic conditions.

Variscan $\mathrm{D}_{1}$ deformation produced NW-SE trending asymmetric NE-vergent folds in the upper structural levels, and NE-vergent large-scale recumbent folds and thrust sheets in the lower structural levels. These early Variscan compressional structures were variably overprinted during the $D_{2}$ extensional event (Escuder Viruete et al. 1994) with large-scale, sub-horizontal shear zones delimiting rocks with different metamorphic grade (upper and lower units, Escuder Viruete 1998). Subsequently, Variscan $D_{3}$ structures produced upright, open to tight folds of centimeter to kilometer wavelength responsible for the presentday structure of the dome (Iglesias and Choukroune 1980; López-Plaza 1982) (Fig. 2). Coeval with or post-dating the $\mathrm{D}_{3}$ deformation event, western Iberia was affected by largescale ductile strike-slip shear zones dated at ca. $308 \mathrm{Ma}$ $\left({ }^{40} \mathrm{Ar} /{ }^{39} \mathrm{Ar}\right.$ on muscovite, Gutiérrez-Alonso et al. 2015). The most prominent of these shear zones in the TD is the sinistral Juzbado-Penalva Shear Zone and its conjugated shear zones (the sinistral Pelazas Shear Zone and the dextral NW striking Fermoselle Shear Zone) (Fig. 2), which are responsible for the sigmoidal foliation pattern found throughout the whole area. These large-scale shear zones are coeval with the post-Variscan counterclockwise rotation of the TD during the generation of the Cantabrian Orocline (or Ibero Armorican Arc, Fig. 1) as revealed by recent paleomagnetic studies in this region and its surroundings (Fernández-Lozano et al. 2016; Pastor-Galán et al. 2016).

\section{Previous geochronology}

The timeframe of the geological evolution of the area has been largely inferred from structural relationships, some of which are bracketed by units whose age is poorly constrained. The compressional $\mathrm{D}_{1}$ deformation that led to Barrovian-type upper amphibolite facies metamorphism $\left(\mathrm{M}_{1}\right)$, in the lower unit, is interpreted to have peaked at ca. 332-337 Ma in the Tormes Dome (U-Pb ID-TIMS in monazite, Valverde-Vaquero et al. 2007) and ca. $337 \mathrm{Ma}$ in the Somosierra Dome (SD) (U-Pb ID-TIMS in monazite, Escuder Viruete et al. 1998), although recent ${ }^{40} \mathrm{Ar} /{ }^{39} \mathrm{Ar}$ ages in the Somosierra Dome attribute an age of 354-347 Ma to this phase (Rubio Pascual et al. 2013). Major $D_{2}$ extension, which resulted in nearly isothermal decompression from 800-900 to $300 \mathrm{MPa}$ in the TD (Escuder Viruete et al.
2000) and from 1000-1200 to $400 \mathrm{MPa}$ in the SD (Rubio Pascual et al. 2013), was recorded in low-pressure/hightemperature paragenesis $\left(\mathrm{M}_{2}\right)$ and resulted in extensive migmatization and anatexis together with D1 isograd telescoping. These migmatites yielded ages at $325-320 \mathrm{Ma}$ (U$\mathrm{Pb}$ ID-TIMS in monazite, Valverde-Vaquero et al. 2007) and the extensional fabric in the SD gave coeval ${ }^{40} \mathrm{Ar} /{ }^{39} \mathrm{Ar}$ ages between 323 and $314 \mathrm{Ma}$ (Rubio Pascual et al. 2013). These ages are slightly younger than the $334 \mathrm{Ma} \mathrm{Rb}-\mathrm{Sr}$ whole-rock isochron age of Beetsma (1995; recalculated with the ${ }^{87} \mathrm{Rb}$ decay constant recommended by IUGS; Villa et al. 2015) for coarse-grained two mica granites from the Barruecopardo area (Fig. 2) and the emplacement age of the biotite \pm muscovite porphyritic granites in the neighborhood ( $320 \pm 5$, U-Pb ID-TIMS on monazite, Ferreira et al. 2000; $319 \mathrm{Ma}$ U-Pb ID-TIMS on zircon, Gomes et al. 2014; 318-322 Ma U-Pb-Th in monazites, Gloaguen 2006; Gloaguen et al. 2006; 322-317 Ma U-Pb ID-TIMS on zircon, Costa et al. 2014; 330-321 Ma U-Pb SHRIMP, Díez Fernández and Pereira 2017). Migmatization temperatures may have persisted locally at lower-middle crustal levels as a result of the high thermal gradient inherited from $D_{2}$, as voluminous syn- $\mathrm{D}_{3}$ granitoids yielded slightly younger ages (311 Ma U/Pb monazite, López-Moro et al. 2012; 315-313 Ma U-Pb ID-TIMS, Gomes et al. 2014; 316-310 Ma U-Pb ID-TIMS, Valverde-Vaquero et al. 2007; $316 \pm 9$ and $311 \pm 7 \mathrm{Ma}$ U-Pb SHRIMP, Díez Fernández and Pereira 2017). These ages are also in agreement with the ages obtained in other gneiss-cored domes along the Ibero-Armorican Arc (Augier et al. 2015). Late strike-slip movements along the Juzbado-Penalva and related shear zones have been dated at $308 \mathrm{Ma}$ (GutiérrezAlonso et al. 2015 and references therein).

\section{Field description and petrography}

About $65 \%$ of the plutonic rocks from the TD consist of equigranular two-mica granites, including coarse-grained types (average mineral diameter $4 \mathrm{~mm}$, alkali feldspar crystals being larger than the rest), medium-grained $(\varnothing=1.55 \mathrm{~mm})$, and fine-grained $(\varnothing=1.03 \mathrm{~mm})$ granite types. They occur as sheet-like intrusions on the outcrop to the pluton scale (López-Plaza and López-Moro 2004). Five representative samples (Figs. 2, 3) from four syn-kinematic granitoids of the TD were collected for U-Pb LA-ICP MS dating to constrain their intrusion age and their possible protoliths. The analyzed samples are from plutons of the migmatized TD, except for sample BARR that is from the epizonal Barruecopardo pluton.

All studied granitoids are peraluminous, with an $\mathrm{A} / \mathrm{CNK}$ index between 1.13 and 1.28. They are enriched in incompatible and mobile elements, especially $\mathrm{Rb}$ and $\mathrm{K}$. REEs 


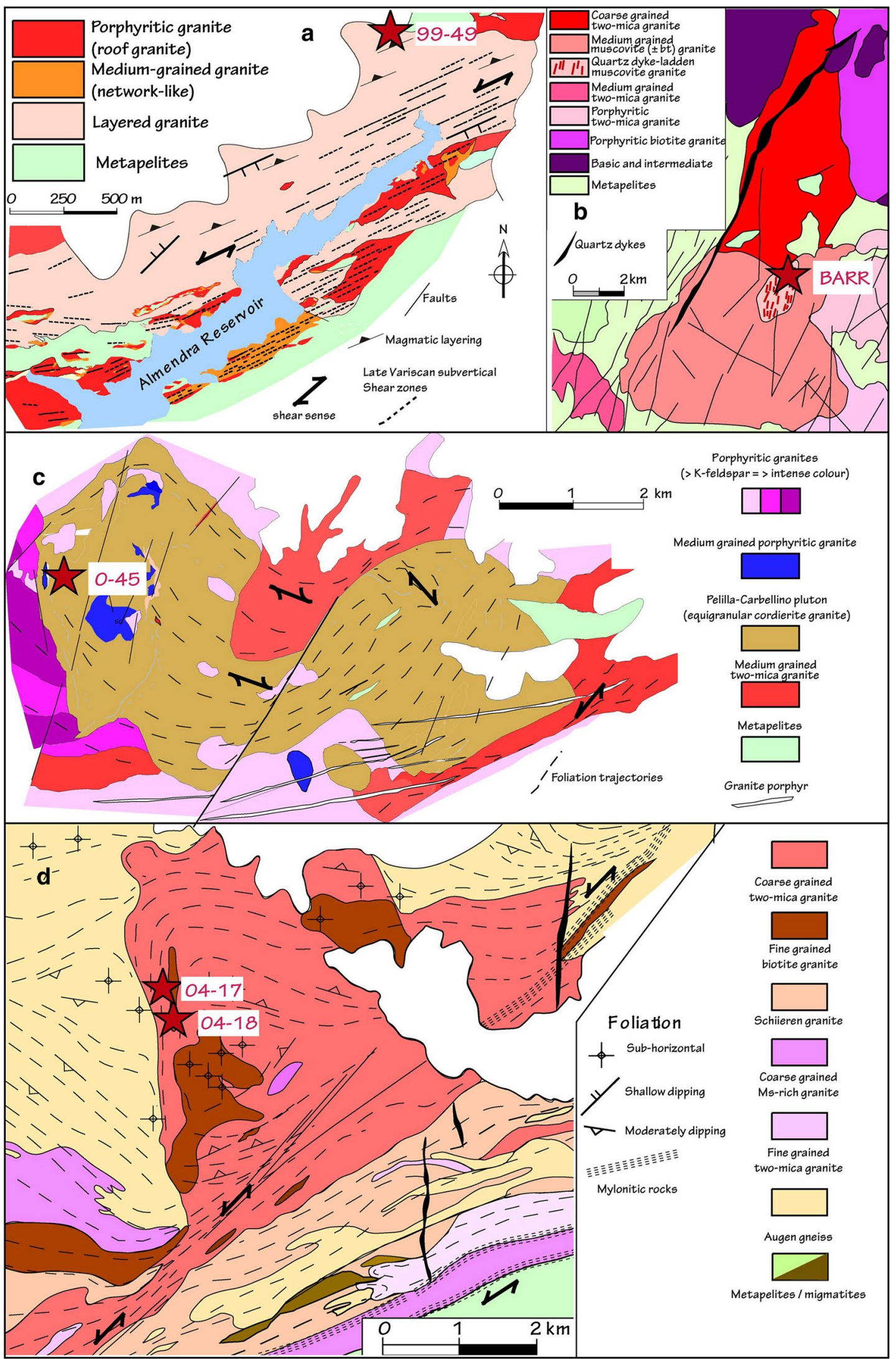

Fig. 3 Detailed maps depicting the lithologies and structures in the surroundings of each of the samples studied in this work 
are fractionated and have high $(\mathrm{La} / \mathrm{Lu})_{\mathrm{n}}$ ratios (between 28 and 75). They show negative anomalies for $\mathrm{Ba}, \mathrm{Sr}, \mathrm{Eu}$, and especially $\mathrm{Nb}$ and Ti. Whole-rock oxygen isotope analyses yielded $\mathrm{O} \delta^{18}$. values between 10.3 and $12.9 \%$. These geochemical features are all characteristic for S-type granitoids with crustal affinity (e.g., López-Plaza et al. 2008; LópezMoro et al. 2012).

\section{Cordierite-bearing granites from the Pelilla complex (Sample O-45)}

The Pelilla complex (Fig. 3c) is a WNW-ESE trending elongated body mainly composed of K-feldspar-rich cordierite granites. A sinistral NE-trending shear zone transecting the pluton controls both the pluton shape and the weak internal foliation. The cordierite granites contain (average of six samples): quartz (21.6 vol\%), K-feldspar (37.8\% vol\%), plagioclase $(21.8 \mathrm{vol} \%)$, muscovite $(8.6 \mathrm{vol} \%)$, biotite (4.6 vol\%), cordierite ( $4.5 \mathrm{vol} \%$, may reach locally up to $30 \mathrm{vol} \%)$, and accessory sillimanite, andalusite, apatite, zircon, monazite, and opaque minerals. Their composition is monzogranitic, although some of the coarse-grained facies are classified as quartzsyenites. The large K-feldspar megacrysts up to $3 \mathrm{~cm}$ are equant and define an apparent isotropic fabric and panidiomorphic texture. Rapakivi texture is not uncommon and consists of mantled feldspars with a subhedral core of K-feldspar rimmed by oligoclase. Anorthite composition of zoned plagioclase crystals ranges from $\mathrm{An}_{25}$ to albite, although oscillatory zoning may also be present in the core. Sillimanite-rich enclaves are surrounded by cordierite that together with the occurrence of andalusite indicate relatively low-pressure conditions during granite emplacement.

\section{Porphyritic two-mica \pm sillimanite granites from the Pelazas pluton (Sample 99-49)}

Porphyritic two-mica \pm sillimanite granite and mediumgrained two-mica granite constitute the Pelazas pluton (Fig. 3a, López-Plaza and López-Moro 2008). This pluton was affected by the Pelazas Shear Zone (López-Plaza 1982), a N70 ${ }^{\circ} \mathrm{E}$ trending sinistral shear zone (Fig. 2). Porphyritic two-mica \pm sillimanite granites contain abundant pegmatites as well as irregular and elongated K-feldsparrich pockets at the top of the pluton (dated roof facies) or in sheet-like structures (layered facies). Layered facies may show modal graded layers in the northernmost part of the Pelazas Pluton, where their rhythmic nature corresponds to the B-type of Naslund and McBirney (1996). The layered granite of the Pelazas pluton typically contains swarms of biotite schlieren with gradual transitions from the modal graded layered zone to the schlieren zone. Schlieren are composed of thin, wavy streaks of biotite, sillimanite, and quartz, as well as secondary muscovite. They may be equivalent to the "wispy or streaky layering" of Barrière (1981). The layers of the modal graded layered zone, ranging between $10 \mathrm{~cm}$ to more than $1 \mathrm{~m}$ in thickness, typically are outward-dipping. The bottom layer commonly shows a thin, almost continuous, biotite-rich lamina. Centimeter-scale biotite- and sillimanite-rich xenoliths are found mainly towards the bottom. Modal grading is not regular, with a general increase of biotite, plagioclase, sillimanite, muscovite, quartz, and accessory minerals and a decrease of K-feldspar towards the bottom. The composition of plagioclase rims changes slightly from the top to the bottom of these layered structures, with values of $\mathrm{An}_{13}$ at the top down to $\mathrm{An}_{04}$ at the bottom (López-Plaza and López-Moro 2008). Two types of muscovite occur: subhedral muscovite commonly associated with biotite and late muscovite, which may be simplectitic in association with sillimanite or palm-like.

\section{Coarse-grained two-mica granites and fine-grained biotite \pm muscovite granites of the Ledesma pluton [Samples 04-17(coarse) and 04-18 (fine-grained)]}

Coarse-grained two-mica granite (CTMG) and a finegrained biotite \pm muscovite granite (FBG) are the two main granite types of the Ledesma pluton (Fig. 3d), an asymmetric drop-shaped pluton with two contrasting fabrics: a sub-vertical fabric in the external contacts and a widespread flat-lying fabric at the center of the pluton. The sub-vertical fabric is related to strike-slip deformation along the Juzbado-Penalva Shear Zone (Figs. 2, 3d) (307$308 \mathrm{Ma}$ according to Valle Aguado et al. (2005) and Gutiérrez-Alonso et al. 2015). The flat-lying fabric seems to have a tectonic origin as foliation passes through enclaves and internal contacts of the plutons (López-Plaza and LópezMoro 2008). The concentric foliation pattern may also suggest a certain effect of radial expansion (Fig. 3d). The FBG is slightly porphyritic, shows xenoliths of migmatites and augen gneiss, as well as xenocrysts of K-feldspar, the latter being more common towards the top of the body. Microgranular mafic enclaves of tonalitic and granodioritic composition are common in this granite type. The modal composition (average of four samples) is as follows: quartz (31 vol\%), alkali feldspar (24 vol\%), plagioclase (28 vol\%), biotite (10 vol\%), and muscovite $(5 \mathrm{vol} \%)$ as essential minerals, and apatite, zircon, and monazite as accessories. The CTMG has an equigranular texture, although it may be locally slightly porphyritic or show schlieren. The modal composition (average of four samples) is as follows: quartz (35\% vol\%), alkali feldspar (32 vol\%), plagioclase (19 vol\%), biotite (6 vol\%), and muscovite (7 vol\%) as essential constituents, and apatite, zircon, monazite, sillimanite, and cordierite. Andalusite is relatively common, 
occurring in pegmatitic pockets as well as around sillimanite-rich enclaves within the granite. The biotite composition allows both granite types to be discriminated, with more aluminic biotite in the CTMG relative to those of FBG, which leads to their plotting in different fields (aluminopotassic and calc-alkaline, respectively) in the diagram of the Nachit et al. (1985). Although contrasting structural relations have been found (López-Plaza 1980; López-Plaza and López-Moro 2008) both granites are probably coeval.

\section{Medium-grained muscovite \pm biotite granite of the Barruecopardo tungsten mining district (Sample BARR)}

This granite hosts one of the most important tungsten mineralizations in Spain. The intrusion is a nested pluton that displays discordant relationships with other granites to the north and with Ediacaran-Cambrian age metasediments in the andalusite zone to the south (Fig. 3d). The granite exhibits a weak foliation (NW-SE) that is recorded by scarce biotite. The pluton consists of a volumetrically dominant equigranular medium-grained muscovite \pm biotite granite (MMG) and occasionally a finer-grained facies that has been interpreted as a border facies (Díez Montes et al. 1991). Both facies are compositionally and texturally similar. A swarm of centimeter-scale quartz-veins with scheelite ore crops out within the main facies. These dykes developed a greisenization or feldspatization in their salbands, and an important hydrothermal activity was dated using $\mathrm{K}-\mathrm{Ar}$ in muscovite, yielding a Permian age $(287 \pm 5 \mathrm{Ma}$, Antona 1991). The main facies (MMG) exhibits a conspicuous "fly wing" texture with big crystals of biotite of 4-5 $\mathrm{mm}$ in size that stands out in a quartz-feldspathic mesostasis of 2-3 $\mathrm{mm}$ in size, where alkali feldspar phenocrysts up to $15 \mathrm{~mm}$ in size can also be found. Enclaves are rare and small, but decametric country-rock enclaves have been occasionally found in the open-pit of Coto Merladet mine. Petrographically, the main facies is a medium inequigranular granite consisting of quartz (35 wt\%), alkali feldspar $(17.5 \mathrm{wt} \%)$ with scarce perthites, plagioclase (25 wt $\left.\% ; \mathrm{An}_{10-01}\right)$, muscovite (15.5 wt \%), and biotite (6 wt\%) as their main constituents and minor amounts of apatite, zircon, monazite, rutile, and sillimanite, the latter either as needles or prismatic crystals, but always enclosed in muscovite. Quartz with undulose extinction and straight borders, plagioclase with curved twin planes and undulose extinction and micas showing curved cleavage planes and incipient mica fish structures are petrographic features that point to a deformation in ductile conditions according to Passchier and Trouw (2005). It should be noted that the main facies suffered a pervasive overprint of subsolidus recrystallization, with a feldespatization of plagioclase and an overall muscovitization that mainly affected the biotite.

\section{Analytical procedures}

Zircon and monazites were separated at the GeoForschungsZentrum Helmholtz-Zentrum Potsdam (Germany) and in the University of Salamanca (Spain). Approximately $3 \mathrm{~kg}$ of sample was crushed in a jaw crusher and sieved for the fraction $63-400 \mu \mathrm{m}$. Concentrates were obtained by using Wilfley table, Frantz isodynamic magnet separator, and heavy liquids (bromoform and diiodomethane). Inclusion-free, perfectly clear monazite crystals and zircon grains were selected from these concentrates by hand-picking under a binocular microscope.

Monazite fractions with a ${ }^{205} \mathrm{~Pb}_{-}{ }^{235} \mathrm{U}$ mixed tracer were dissolved overnight in concentrated $\mathrm{H}_{2} \mathrm{SO}_{4}$ at $220{ }^{\circ} \mathrm{C}$ on the hot plate. $\mathrm{Pb}$ and $\mathrm{U}$ were separated using a $\mathrm{HBr}-\mathrm{HCl}$ and $\mathrm{HCl}-\mathrm{HNO}_{3}$ ion-exchange chromatography procedure, respectively, and were loaded together with silica emitter on single Re-filaments, and were measured at 1200-1260 and $1350-1400{ }^{\circ} \mathrm{C}$, respectively, on a Finnigan MAT262 multicollector mass-spectrometer using Faraday collectors and ion counting at Deutsches GeoForschungsZentrum. The $\mathrm{U}-\mathrm{Pb}$ analytical data obtained for monazite are shown in Table 1 (Supplementary material).

Zircon crystals of all grain sizes and morphological types were selected, mounted in resin blocks and polished to half their thickness at the Museum für Mineralogie und Geologie (Senckenberg Naturhistorische Sammlungen Dresden). All grains were documented by back-scattered electron (BSE) and cathodoluminiscence (CL) images using a SEM coupled to a HONOLD CLdetector operating with a spotsize of $550 \mathrm{~nm}$ at $20 \mathrm{kV}$ to study their internal structure and to select the best areas for laser ablation (Fig. 4). Zircon was analyzed for U, $\mathrm{Th}$, and $\mathrm{Pb}$ isotopes by LA-ICP-MS, using a ThermoScientific Element 2 XR sector field ICP-MS coupled to a New Wave UP-193 Excimer Laser System. A teardropshaped, low volume laser cell by Ben Jähne (Dresden, Germany) was used to enable sequential sampling of heterogeneous grains (e.g., growth zones) during time resolved data acquisition. Each analysis consisted of approximately $15 \mathrm{~s}$ background acquisition followed by $35 \mathrm{~s}$ data acquisition, using a laser spot-size of $25 \mu \mathrm{m}$. Sixty zircon crystals were analyzed from each sample. A common- $\mathrm{Pb}$ correction based on the interference- and background-corrected ${ }^{204} \mathrm{~Pb}$ signal and a model $\mathrm{Pb}$ composition (Stacey and Kramers 1975) was carried out if necessary. Analyses with discordance higher than $10 \%$, (calculated as the difference between the ${ }^{206} \mathrm{~Pb} /{ }^{238} \mathrm{U}$ and the ${ }^{207} \mathrm{~Pb} /{ }^{206} \mathrm{~Pb}$ ages) were rejected. Raw data were corrected for background signal, common $\mathrm{Pb}$, laser-induced elemental fractionation, instrumental mass discrimination, and time-dependent elemental fractionation of $\mathrm{Pb} /$ $\mathrm{Th}$ and $\mathrm{Pb} / \mathrm{U}$ using an $\mathrm{Excel}^{\circledR}$ spreadsheet program 
Fig. 4 CL images of representative zircon grains dated in this study with ablation points and corresponding ages. aXX stands for the analysis number in each of the samples (Tables 2-6 in supplementary material)
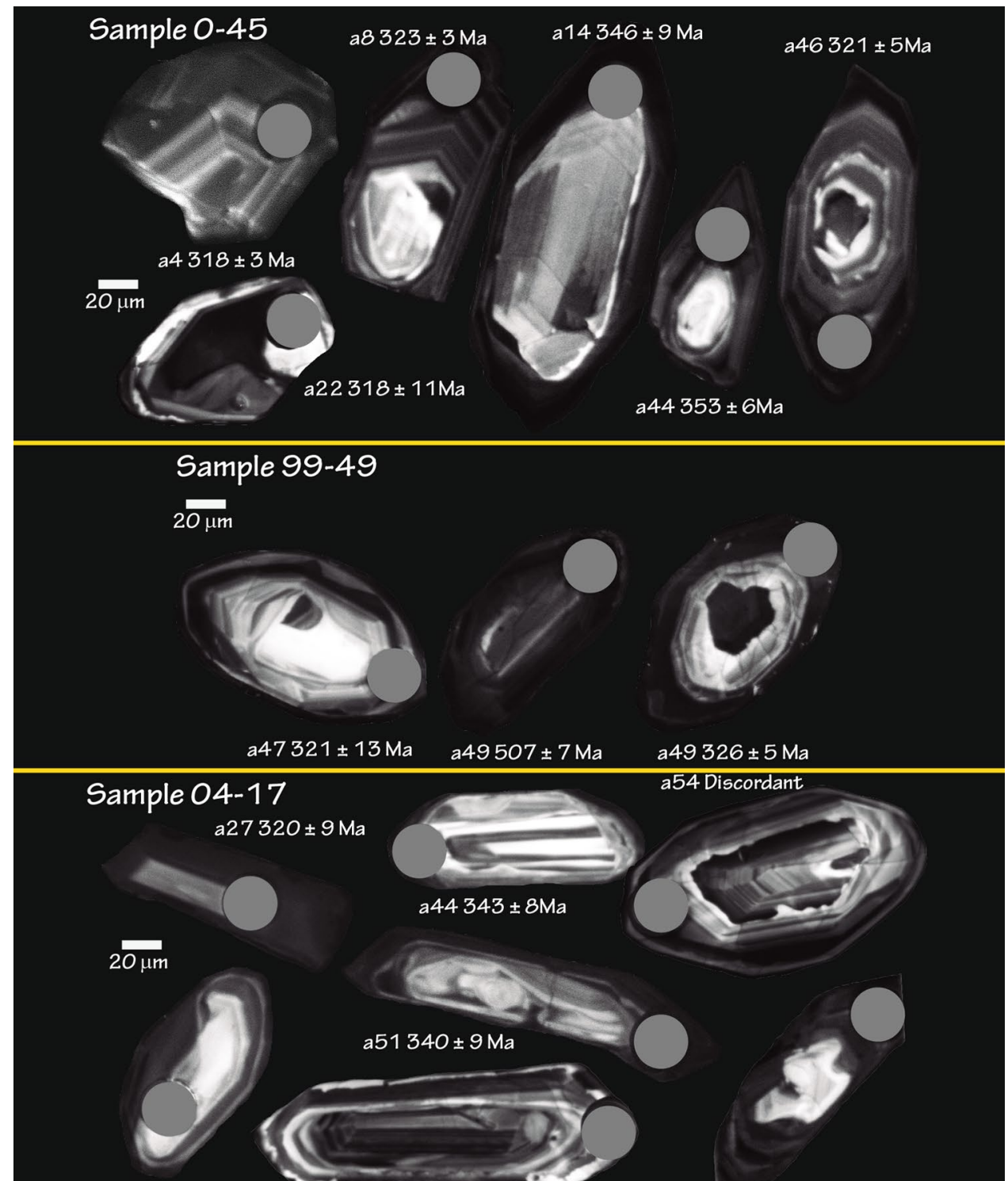
a54 Discordant
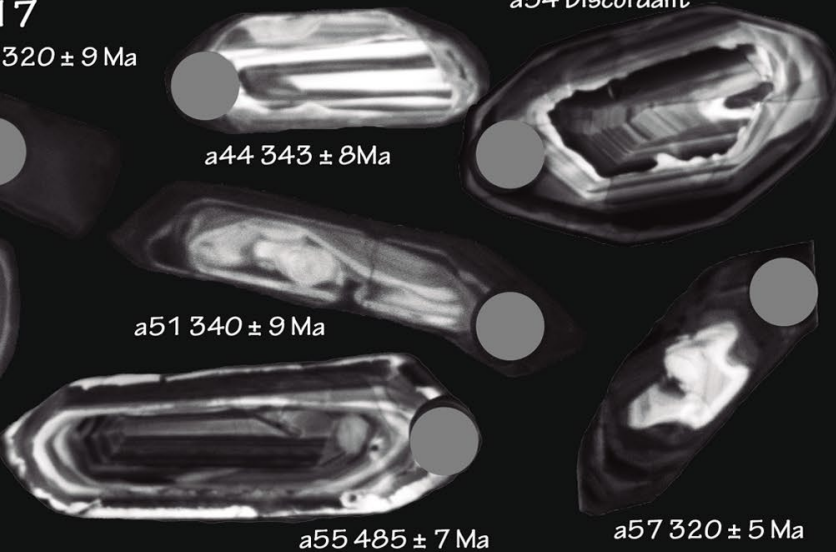

a49341 $\pm 12 \mathrm{Ma}$

$\mathrm{a} 55485 \pm 7 \mathrm{Ma}$

a57 $320 \pm 5 \mathrm{Ma}$

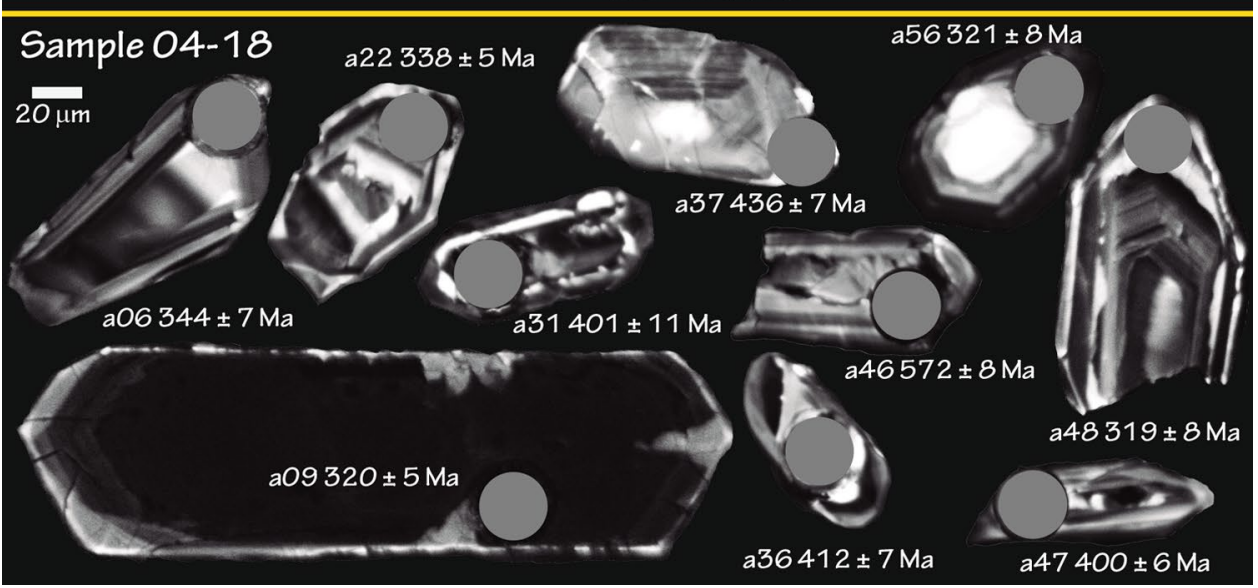


developed by Axel Gerdes (Institute of Geosciences, Johann Wolfgang Goethe-University Frankfurt, Frankfurt am Main, Germany). Reported uncertainties were propagated by quadratic addition of the external reproducibility obtained from the standard zircon GJ-1 ( 0.6 and $0.5-1 \%$ for the ${ }^{207} \mathrm{~Pb} /{ }^{206} \mathrm{~Pb}$ and ${ }^{206} \mathrm{~Pb} /{ }^{238} \mathrm{U}$, respectively) during individual analytical sessions and the within-run precision of each analyses. Concordia diagrams $(2 \sigma$ error ellipses) and concordia ages (95\% confidence level) were produced using Isoplot/Ex 3.75 (Ludwig 2012). The ${ }^{206} \mathrm{~Pb} /{ }^{238} \mathrm{U}$ ages were taken for interpretation and building probability density plots when appropriate. For further details on analytical protocol and data processing, see Frei and Gerdes (2009). The analytical results are shown in Tables 2-6 (supplementary material).

\section{Results}

\section{Pelilla granite (sample 0-45)}

Analyzed zircon crystals are mostly prismatic, showing oscillatory zoning and occasionally inherited cores (Fig. 4). Sixty zircon grains were analyzed, of which 45 yield concordant ages (Table 2, supplementary material). A coherent (concordant and overlapping) group of the 30 younger analyses gives a concordia age of $318 \pm 1 \mathrm{Ma}$, which is interpreted to represent the crystallization/intrusion age of this granite (Fig. 5). Fifteen zircon grains yield older (concordant) ${ }^{206} \mathrm{~Pb} /{ }^{238} \mathrm{U}$ ages at ca. 350, 500, 550-600, 650, and $1600 \mathrm{Ma}$ (Fig. 5). These older grains are inherited from the protoliths (see discussion below).

\section{Pelazas pluton (sample 99-49)}

Most of the analyzed zircon grains are rounded with low luminescence and cores (Fig. 4). Only 32 of the analyzed zircon crystals provide concordant ages (Table 3, supplementary material) of which the two youngest yield a concordia age of $325 \pm 5 \mathrm{Ma}$ (Fig. 6) that is interpreted to date the crystallization/intrusion age of this pluton. Both zircon crystals are prismatic and show overgrowths (Fig. 4). The other 30 concordant zircon grains are inherited: eleven of them have ${ }^{206} \mathrm{~Pb} /{ }^{238} \mathrm{U}$ ages within the range of the CambroOrdovician magmatic event ("Ollo de Sapo", see above) in Iberia; fifteen analyses yield ages corresponding to the Cadomian cycle (540-840 Ma, Cryogenian-Ediacaran); one is ca. $917 \mathrm{Ma}$ (Tonian); and three have Paleoproterozoic and Archean cores (ca. 2200-2700 Ma).

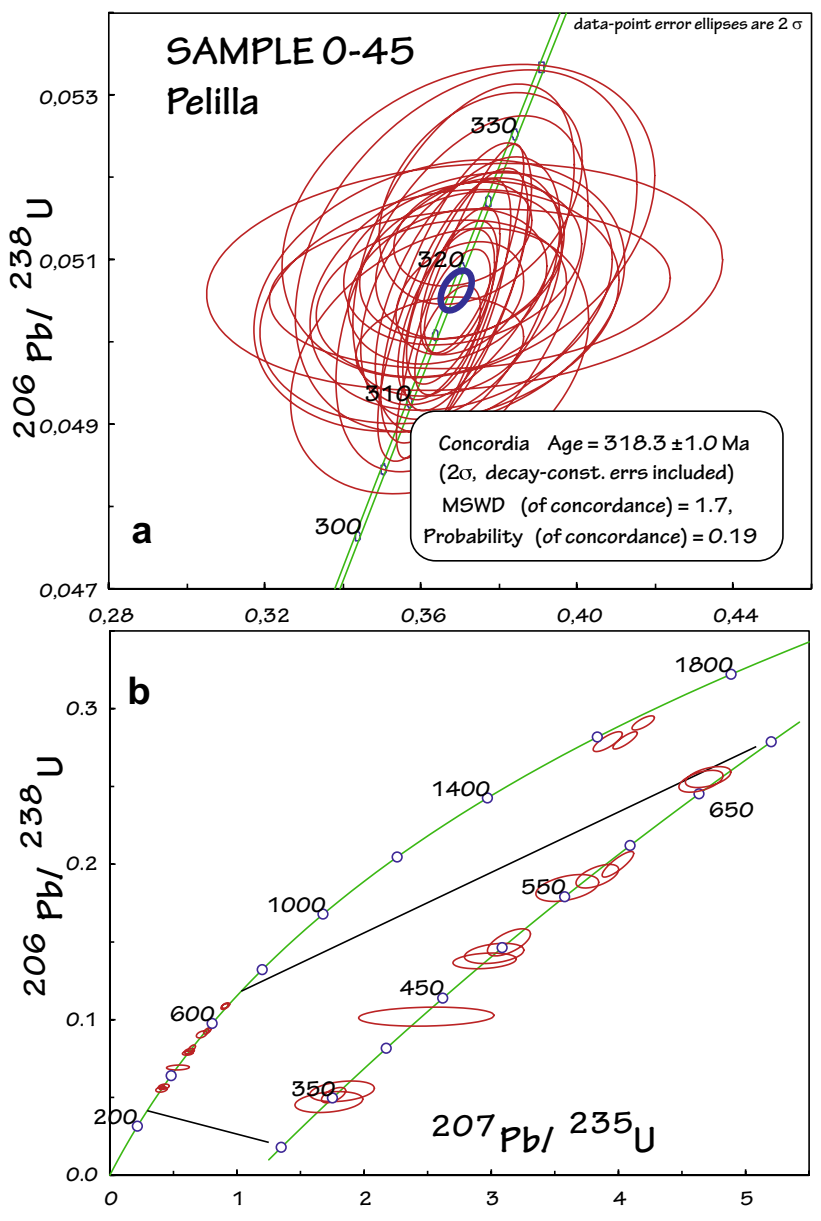

Fig. 5 Concordia diagrams for a magmatic and $\mathbf{b}$ inherited/xenocrystic zircon crystals from sample O-45

\section{Ledesma pluton (sample 04-17, coarse-grained facies)}

Zircon crystals from this sample feature varied shapes, from prismatic to rounded, most of them display core-rim structures with oscillatory overgrowths and some crystals have non-luminescent rims (Fig. 4). Forty-nine zircon grains yield concordant ages (Table 4, supplementary material). A coherent group of the 16 younger analyses defines a concordia age of $318 \pm 2$ Ma (Fig. 7), which is interpreted to be the crystallization/intrusion age of this pluton. The inherited ${ }^{206} \mathrm{~Pb} /{ }^{238} \mathrm{U}$ ages cluster around $340 \mathrm{Ma}$ ( 5 zircon ages), ca. $500 \mathrm{Ma}$ (19 zircon ages attributed to the "Ollo de Sapo" event), $600 \mathrm{Ma}$ (5 zircon grains from the Cadomian cycle), two of Tonian age and an older Archean core.

A single monazite fraction of this granite gave a concordant $\mathrm{U}-\mathrm{Pb}$ age at $343.2 \pm 2.7 \mathrm{Ma}$ (Fig. 7; Table 1, supplementary material), which corresponds to the age of the youngest inherited zircon population. 

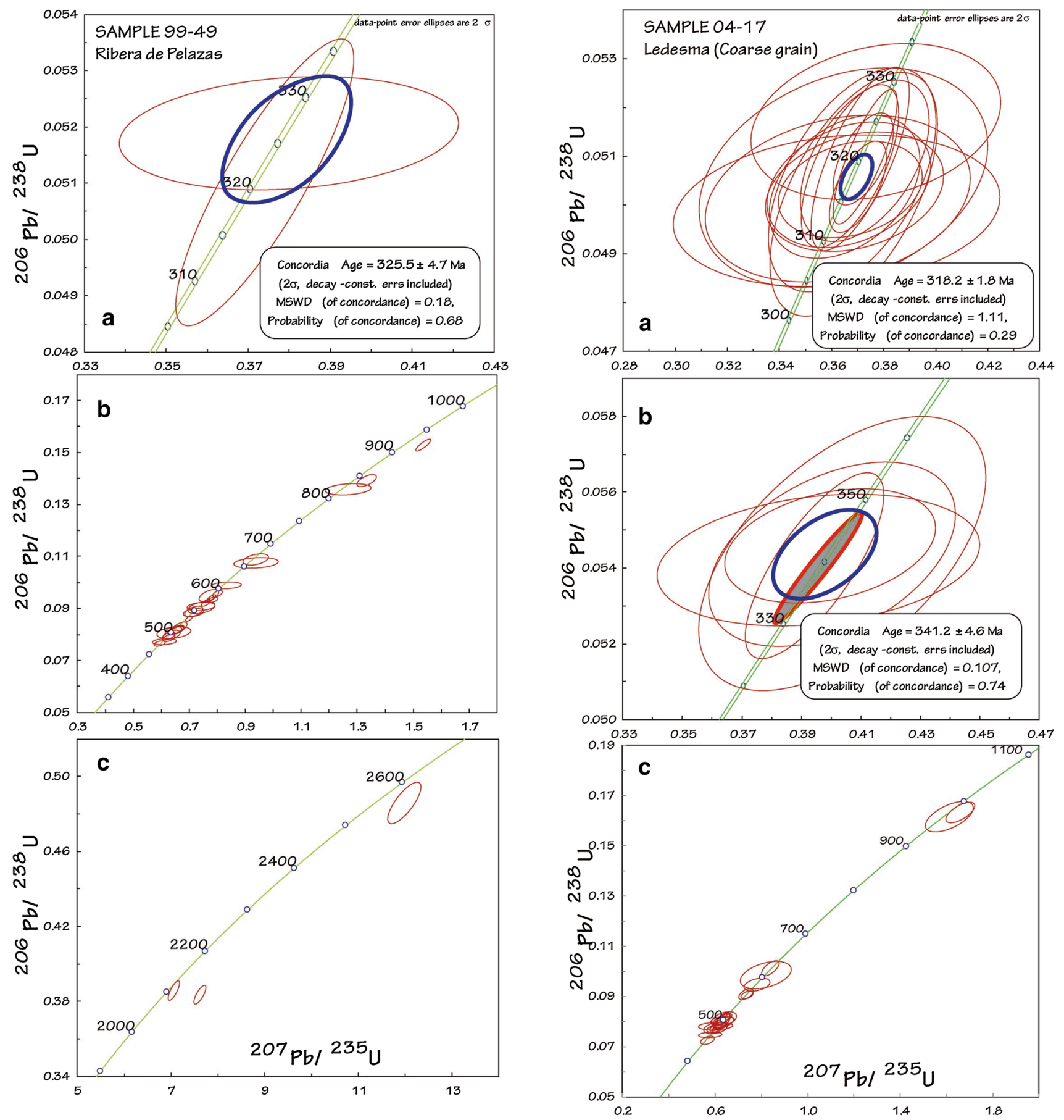

Fig. 6 Concordia diagrams for a magmatic and b, $\mathbf{c}$ inherited/ xenocrystic zircon from sample 99-49

\section{Ledesma pluton (sample 04-18, fine-grained facies)}

This sample was collected ca. $100 \mathrm{~m}$ SE of sample 04-17, at a fine-grained NS elongated body within the Ledesma pluton. Forty-six out of the 60 analyses give concordant ages (Table 5, Supplementary material). The age of crystallization is tightly constrained by a concordia age of $318 \pm 2.5 \mathrm{Ma}$ (identical to that of sample 04-17) obtained

Fig. 7 Sample 04-17 has two types of magmatic zircon yielding different ages. Concordia diagram (a) shows magmatic zircon ages interpreted to date the crystallization age. Concordia diagram (b) shows magmatic zircon inherited from a magmatic event at ca. $340 \mathrm{Ma}$. Inherited/xenocrystic zircon data are shown in c. The bold (gray) ellipse in $\mathbf{b}$ represents the age of a single concordant monazite fraction dated by TIMS

from a coherent group of analyses from 8 prismatic zircon crystals (Fig. 8) displaying magmatic oscillatory growth patterns or non-luminescent areas (Fig. 4). Zircon crystals 


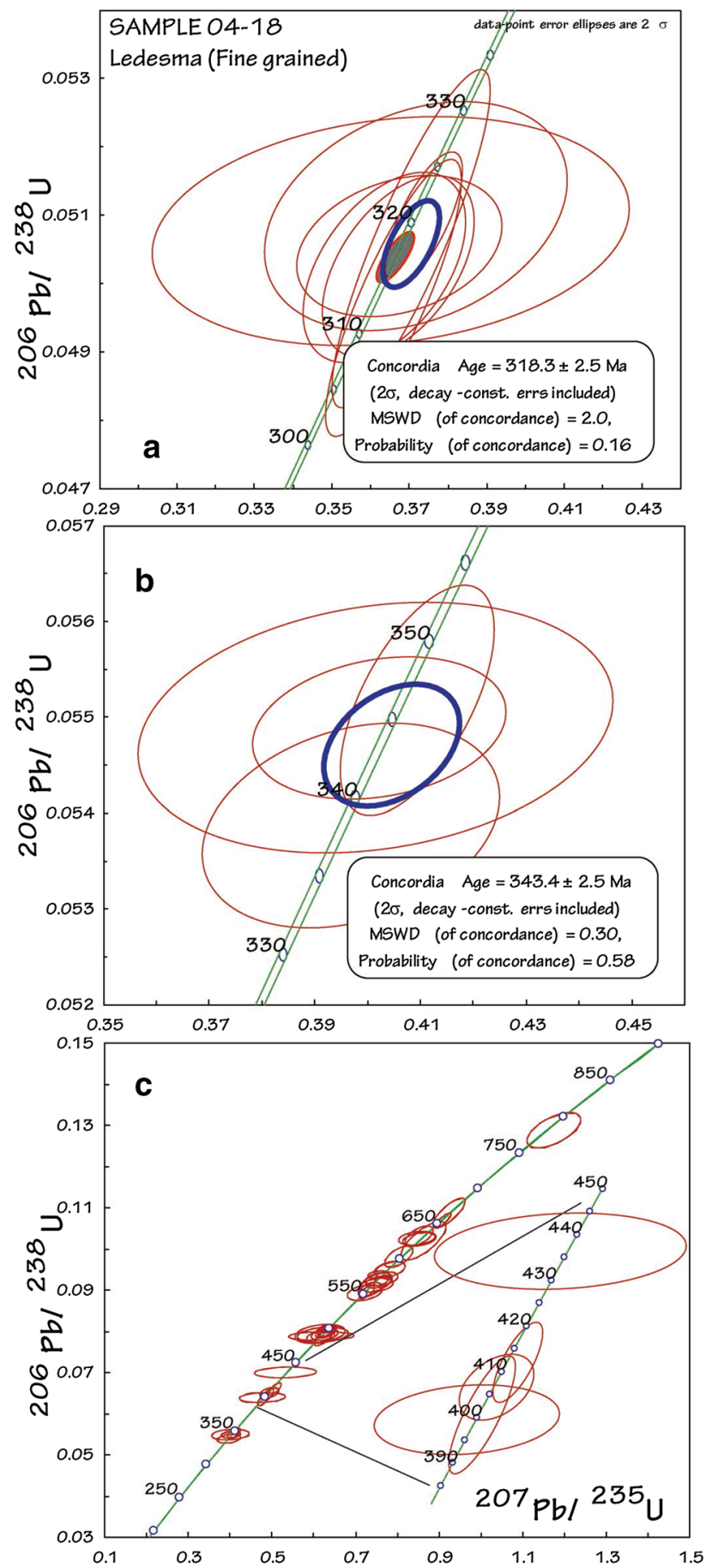

Fig. 8 Concordia diagrams for a magmatic zircon interpreted to date the crystallization age, b magmatic zircon from a ca. $343 \mathrm{Ma}$ old magmatic event, and $\mathbf{c}$ older inherited/xenocrystic zircon crystals obtained from sample 04-18. The bold ellipse in a represents the age of a concordant monazite fraction dated by TIMS

with older concordant ages are inherited. Four zircon grains have ${ }^{206} \mathrm{~Pb} /{ }^{238} \mathrm{U}$ ages ranging from 338 to $346 \mathrm{Ma}$ yielding a pooled concordia age of $343 \pm 2.5 \mathrm{Ma}$ (Fig. 8). An older group of five zircon grains yields Devonian ${ }^{206} \mathrm{~Pb} /{ }^{238} \mathrm{U}$ ages ranging from 400 to $436 \mathrm{Ma}$. The youngest four zircon crystals of this group yield a pooled concordia age of $405 \pm 3.5$ Ma. Uppermost Cambrian zircon crystals (10) with ${ }^{206} \mathrm{~Pb} /{ }^{238} \mathrm{U}$ ages ranging from 489 to $500 \mathrm{Ma}$ are attributed to the "Ollo de Sapo" event. Eighteen zircon grains of Cadomian age were also identified within the concordant inherited population $\left({ }^{206} \mathrm{~Pb} /{ }^{238} \mathrm{U}\right.$ ages of $\left.552-781 \mathrm{Ma}\right)$ and, finally, a Paleoproterozoic age (ca. $2000 \mathrm{Ma}$ ) was found in an inherited core.

A single monazite fraction of this granite gave a concordant U-Pb age at $318 \pm 1.4 \mathrm{Ma}$ (Fig. 8; Table 1, Supplementary material), consistent with the crystallization age interpreted from zircon analyses.

\section{Barruecopardo leucogranite (sample BARR)}

The sample from the Barruecopardo leucogranite pluton (Pellitero et al. 1976; Arribas 1979; Antona et al. 1992; Sanderson et al. 2008) was collected in a part of the intrusion that hosts a tungsten mineralization that forms a steeply east-southeast dipping sheeted vein system. The veins are made up mainly of quartz, arsenopyrite, and scheelite. Forty-two out of the 60 analyses yielded concordant ages (Table 6, Supplementary material). A coherent group of eleven analyses yields a pooled concordia age of $324 \pm 2 \mathrm{Ma}$ (Fig. 9) that is considered to be representative of the crystallization/emplacement age of the Barruecopardo pluton. The majority of the inherited zircon grains (28) have ages within a narrow ${ }^{206} \mathrm{~Pb} /{ }^{238} \mathrm{U}$ age span from 334 to $348 \mathrm{Ma}$ and yield a concordia age of $344 \pm 1 \mathrm{Ma}$ (Fig. 9). Only three older inherited zircon grains were analyzed in this sample: one of them of Devonian age $\left({ }^{206} \mathrm{~Pb} /{ }^{238} \mathrm{U}\right.$ age of $\left.390 \mathrm{Ma}\right)$ and two of them of Ediacaran age $\left({ }^{206} \mathrm{~Pb} /{ }^{238} \mathrm{U}\right.$ age of 543 and $\left.563 \mathrm{Ma}\right)$ (Fig. 9).

\section{Discussion}

The studied samples from the Tormes Dome have yielded intrusion/crystallization ages that cluster around ca. $320 \mathrm{Ma}$, which provide tight constraints on the age of the extensional activity of this sector of the Variscan belt in Iberia. The intrusion ages are in agreement with previous ages obtained in the Tormes Dome and other gneiss-cored domes in the surrounding areas (see above). Despite the presence of a younger voluminous magmatic event at ca. 310-295 Ma that is represented by nearby large plutons (Gutiérrez-Alonso et al. 2011 and references therein), there is no evidence for growth of new zircon during a thermal overprint or isotopic disturbance of the U-Pb system in the coherent group of 66 zircon ages (from all samples) considered to be of magmatic origin (i.e., crystallized from the anatectic melts that formed the studied plutons). 

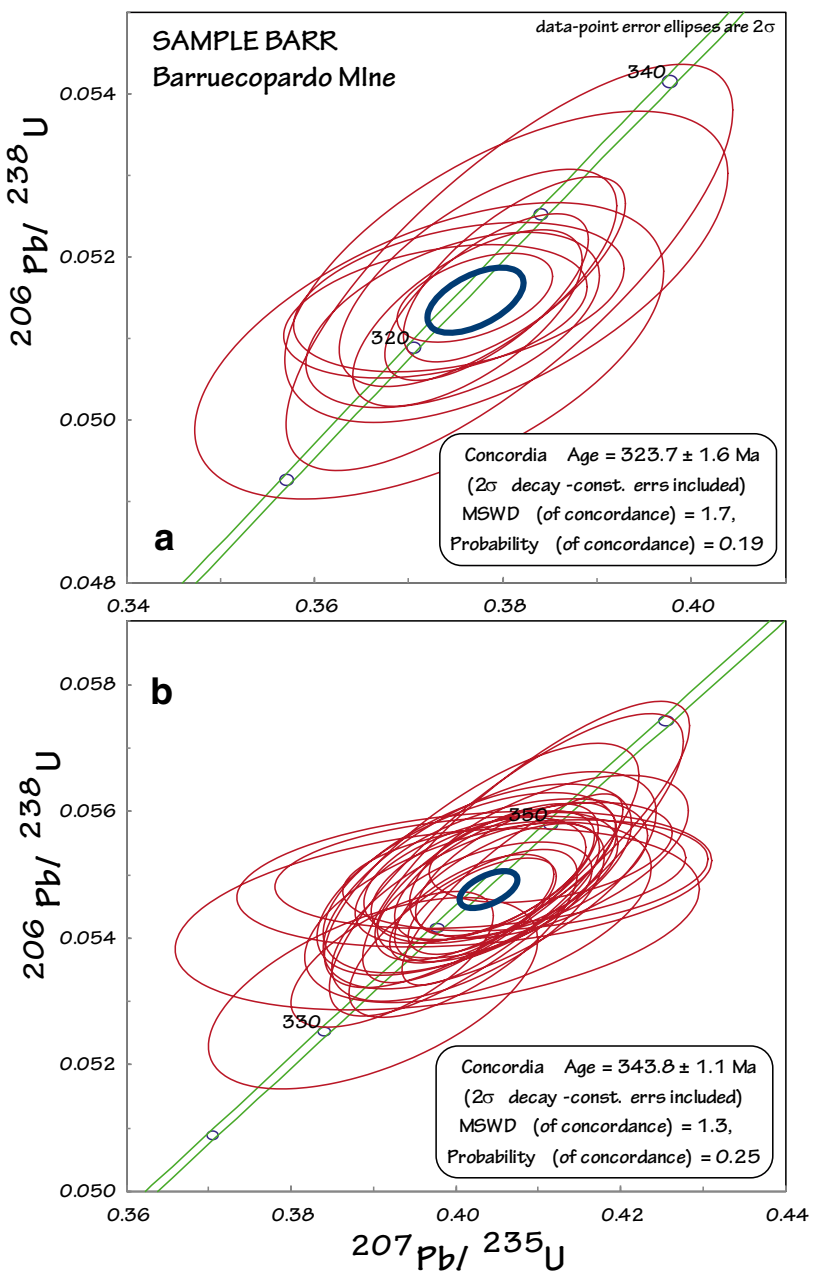

Fig. 9 Concordia diagrams for a magmatic zircon interpreted to date the crystallization age and b magmatic zircon related to a ca. $343 \mathrm{Ma}$ old event obtained from sample BARR

The variable proportion of magmatic and inherited zircon crystals in the various granite samples largely reflects whether inherited zircon grains derived from the protoliths were dissolved or preserved in the granitic melt. Dissolution of inherited zircon depends on $\mathrm{Zr}$-saturation of the melt, which, in turn, depends on melt composition and melting temperature (e.g., Boehnke et al. 2013). A significant portion of inherited zircon may derive from xenolithic material and restitic schlieren incorporated into the melt. Xenolithic and restitic material may also contain monazite or xenotime, i.e., allow for the apparent inheritance of these minerals. Sample 0-45, which has the apparent highest portion of magmatic zircon $(>60 \%)$, is derived from a feldspar-enriched cumulate in a cordierite-bearing granite (López-Plaza and López-Moro 2008), whereas sample 99-49, which has rare magmatic zircon crystals (apparently $<5 \%$ ), shows ubiquitous schlieren, layering, varied internal flow structures and centimeter-scale pelitic xenoliths



Fig. 10 Diagram depicting the relative proportions of magmatic and inherited/xenocrystic zircon grouped according to age. For details and explanation of the chosen intervals, see text

indicative for entrainment of older material (López-Plaza and López-Moro 2008).

The 145 inherited xenocrystic zircon grains found in the studied anatectic granitoids provide data on the possible sources of the melts and the results also shed light on the crustal components of western Iberia. The ages of the inherited zircon grains define five distinct groups that are found in different proportions in the five studied samples (Fig. 10). From younger to older, these age groups are as follows:

1. Carboniferous zircon crystals (ca. $345 \mathrm{Ma}$ ). This group includes 40 zircon crystals with ages ranging from $334 \pm 8$ to $357 \pm 8$ Ma. Zircon crystals of this group are present in samples O-45 (Pelilla), 04-17, 04-18 (Ledesma) and are particularly abundant in sample BARR (Fig. 10). This age is not only restricted to inherited zircon but also has been found in monazite (344 Ma) from granite sample 04-17.

2. Devonian-Silurian zircon crystals. This group is represented by only six zircon grains with scattered ages between ca. 390 and 432 Ma. Zircon grains of this group were found in samples O-45, 04-18 and BARR (Fig. 10).

3. Upper Cambrian-Ordovician zircon crystals. Fortythree zircon grains were identified and their age ranges from ca. 450 to $511 \mathrm{Ma}$. This age group is present in all samples except in sample BARR.

4. Ediacaran-Cryogenian zircon grains (ca. 540$840 \mathrm{Ma}$ ). There are 44 zircon grains falling within this age range with a peak at ca. 565 Ma (Figs. 10, 11). This age group is present in all samples except in sample BARR. 




Fig. 11 Probability density plot of all concordant zircon ages showing major peaks at ca. $320 \mathrm{Ma}$, ca. $340 \mathrm{Ma}$, and ca. $480 \mathrm{Ma}$

5. Older zircon grains (900-2700 Ma). Eleven zircon crystals yielded ages older than 900 Ma. Different proportions of these older zircon crystals appear in all samples except in sample BARR.

The zircon xenocrysts and inherited cores represent a first-order proxy for the investigated anatectic granites. It should be noted, however, that some protoliths already have inherited zircon populations that may contribute to the age spectrum of the anatectic rocks studied in this work. Based on $\mathrm{Rb}-\mathrm{Sr}, \mathrm{Sm}-\mathrm{Nd}$, and oxygen isotope data, partial melting modeling, and experimental and thermodynamic approaches, the main sources for the anatectic granites of the Tormes Dome have been interpreted to be the Ediacaran to Early Cambrian "Schist-Greywacke sedimentary Complex" and/or the uppermost Cambrian to Middle Ordovician "Ollo de Sapo" magmatic rocks (Holtz and Barbey 1991; Castro et al. 2000; Bea et al. 2003; López-Plaza et al. 2008; García-Arias and Corretgé 2010; López-Moro et al. 2012). Our new data on zircon xenocrysts/cores demonstrate that these Ediacaran to Ordovician rocks represent potential source rocks for the anatectic granites, except for sample BARR that seems not to contain "Ollo de Sapo," Ediacaran-Cryogenian or older zircon crystals. Furthermore, the abundance of 340$350 \mathrm{Ma}$ old inherited zircon indicates that metamorphic rocks, migmatites, and granites of this age group also significantly contributed to the anatectic granites.

\section{Significance of the ca. 400 Ma old zircon ages}

Although there is evidence of ca. 400 Ma magmatic rocks described mostly in the easternmost part of the Variscan belt abundant zircon ages around $400 \mathrm{Ma}$ in NW Iberia are only found in the so called Upper Units and the ophiolite-like rocks present in the allochthonous complexes that are interpreted to represent the closure of the Rheic ocean that caused the Variscan orogeny (e.g., FernándezSuárez et al. 2007; Sánchez Martínez et al. 2011; Kroner and Romer 2013; Arenas et al. 2014; Mateus et al. 2016). Such a source for this group of zircon ages is not permissible as the rocks that contain them were structurally above the rocks that form the Tormes Dome. In addition, rocks from the allochthonous complexes were not likely involved in the production of anatectic melts during the subsequent extension as they were located in the hanging wall of the main detachments (Rubio Pascual et al. 2013 and references therein). There are, however, some scarce volcanic rocks dated at ca. $400 \mathrm{Ma}$ in northwestern and central Iberia (Loeschke 1983; Hall et al. 1997; Gutiérrez-Alonso et al. 2008) whose origin is interpreted as related to the extension of the northern Gondwana passive margin (Pin et al. 2006) caused by the ridge subduction in the northern flank of the Rheic ocean (Gutiérrez-Alonso et al. 2008). A propagating failed rift departing from the newly formed Paleotethys ocean has also been proposed as a cause for this magmatic event (Armendáriz et al. 2008). This event could have been responsible for the emplacement of (minor?) magmatic bodies that may have been later involved in anatectic melting, thus making a small though statistically significant contribution to the inherited population of the studied granitoids.

The presence of the small but significant population of inherited zircon with ages around $400 \mathrm{Ma}$ is an example of how inherited zircon populations in igneous rocks can point to the presence of events poorly (or not at all) constrained by geological studies of exposed rocks. These events may be minor in many cases but they may be even of global significance as could be the case in our study if the ca. $400 \mathrm{Ma}$ event is indeed the far field effect of the subduction of the Rheic Ocean ridge under Laurussia. It is perhaps pertinent to mention that the largest mercury deposit in the world (Almadén in Central Spain) could be related to this event (Hall et al. 1997; Hernández et al. 1999) as could be the intrusion of diabase dyke swarms in the CIZ (López-Moro et al. 2007).

\section{Significance of the ca. 340 Ma old zircon ages}

The abundant (exceptionally so in sample BARR) ca. 340 zircon population lacks a putative source in the neighboring areas, but the large proportion of zircon xenocrysts/ cores of this age found in the TD granites begs the question of whether there was a major and hitherto unrecognized magmatic/migmatitic event of such age in the studied area. Magmatic rocks of such age have only been found in northern and central Iberia in the Cangas do Morrazo 
Vaugnerites (U-Pb in zircon, Gallastegui 2005); the Beariz, Chantada and Carballino granites (U-Pb in monazite cores, Gloaguen 2006; Gloaguen et al. 2006) and volcanic rocks in the southern CIZ (Sierra de San Pedro, Bascones Alvira et al. 1982; Soldevila Bartolí 1992). Igneous rocks of that age have also been reported in Variscan realms that can be correlated with the Central Iberian Zone such as the Cantabrian Zone (Merino-Tomé et al. in press); the Pyrenees (Mezger and Gerdes 2016); the French Massif Central (Galán et al. 1997; Ledru et al. 2001); Corsica (Rossi and Cocherie 1991; Li et al. 2014); see also compilation in von Raumer et al. (2014); and southwestern Iberia (Dallmeyer et al. 1995; Montero et al. 2000; Ordóñez Casado 1998, Ordóñez Casado et al. 2008; Romeo et al. 2006; Jesus et al. 2007; Pin et al. 2008; Pereira et al. 2009, 2015; Braid et al. 2012; Dupuis et al. 2014; Gladney et al. 2014; Cambeses et al. 2015).

In the light of the large number of zircon grains of ca. $340 \mathrm{Ma}$ found in the studied rocks (Figs. 10, 11), and given the widespread presence of magmatic rocks of ca. $340 \mathrm{Ma}$ in the Variscan realm (although there is no consensus on their genesis at orogenic belt scale), it is reasonable to postulate that rocks of such age may indeed be part of the "basement" of the CIZ in general and of the Tormes Dome in particular. Despite the fact that a small proportion of zircon grains of this age are found in the syn-orogenic sediments of the CIZ (Martínez Catalán et al. 2016) and of the Cantabrian Zone, which is the orogenic foreland of the CIZ (Pastor-Galán et al. 2013), magmatic rocks of this age have not yet been described in the study area and/or may have not been yet exhumed and eroded to the surface.

The large variation in the proportions of inherited zircon ages in the studied samples (Fig. 10) raises the issue of whether these variations reflect different volumetric involvements of the crustal sources for each of the studied plutons. As shown in Fig. 11, there are five main zircon populations represented in the studied samples, which are interpreted as representative of the zircon content of the main source rocks. Figure 10 highlights the large variability in the proportions of the different populations from one sample to another which, taken at face value, could be attributed to the presence of a very heterogeneous crustal basement as source for the granitoid melts. In addition to the magmatic zircon ages, the most abundant population corresponds to the ca. 470-490 Ma ones followed by the Cadomian (Ediacaran-Early Cambrian) ones, whose likely sources were the "Ollo de Sapo" magmatic rocks and the Ediacaran "Schist-Greywacke Complex," respectively. The ca. 400 Ma zircon crystals are only present (in low proportions) in three of the studied samples. Despite their apparent scarcity, we consider them to be potentially representative of an unknown source in the basement as discussed above. The ca. 340 Ma population is absent in one of the samples (99-49), scarce $(<10 \%)$ in three of them (O-45, 04-17 and 04-18) and dominant in the BARR sample (ca. $70 \%$ ), which suggests that this source is present, albeit very irregularly distributed in the basement. Such hypothesis is compatible with the presence of plutons of unknown size with intrusion ages around $340 \mathrm{Ma}$ in the CIZ basement and is also in agreement with the lack of extensive Cambro-Ordovician igneous rocks within the upper unit of the Tormes Dome.

\section{Concluding remarks}

In addition to the zircon ages obtained and fully described and discussed previously, in a more general context, this paper makes a contribution to some relevant aspects of the significance of granitoids in the study of crustal growth and evolution. The following issues are in our opinion of interest:

1. This paper contributes yet another example to the "paradox" of why crustal granitoids are essentially very similar to one another "on the surface" but display such a wide range of mineralogical, geochemical and isotopic (both stable and radiogenic) features and thus make classification schemes (such as I-S) a rather weak tool (Chappell and Stephens 1988; Castro et al. 1991, 1999; Roberts and Clemens 1993; Aguilar and Villaseca 2010). To some extent, the data presented herein illustrate that much of the multifariousness of granites (Pitcher 1993) is directly inherited from the complexity of their known or unknown sources.

2. This study shows that crustal recycling/cannibalization may often happen at a fast pace in orogenic scenarios with only short lapses of quiescence; in our case study, it seems plausible that a "crustal layer" of ca. $340 \mathrm{Ma}$ granitoids/migmatites was recycled, partially or totally, only 15-20 My after its emplacement.

3. An open question: The most volumetrically significant granitoid suite in the Variscan belt of North and Central Iberia was produced between ca. 305 and $290 \mathrm{Ma}$, after the main orogenic events (collision and extensional collapse) and its genesis has been linked to lithospheric delamination triggered by oroclinal bending of the mountain belt (Gutiérrez-Alonso et al. 2011). In an imaginary alternative scenario in which oroclinal bending did not occur, would the ca. $320 \mathrm{Myr}$ old crustal leucogranitoids (like those studied herein) have been the last manifestation of Variscan magmatism in Iberia?

Acknowledgements This work has been funded by the Spanish Ministry of Economy and Competitiveness under the project ODRE 
III-Oroclines and Delamination: Relations and Effects (CGL201346061-P) and the project of DGCYT "Geochemical, tectonic and experimental approach of the crustal recycling processes and the mantle-crust interaction: Genesis and emplacement of the granitoids from the Tormes Dome" (CGL2004-06808-C04-04). JFS acknowledges support from Project CGL2016-76438-P (Spanish Ministry of Economy and Competitiveness). Assistance by A. Gärtner, U. Linnemann and R. Kraus at the Senkenberg Museum Dresden is greatly appreciated. P. Villar and D. Mellado from Saloro SLU, provided sample BARR. Insightful reviews by L. Solari and C. Quesada are kindly appreciated. This paper is part of UNESCO IGCP Projects 574: Buckling and Bent Orogens, and Continental Ribbons; 597: Amalgamation and breakup of Pangaea: The Type Example of the Supercontinent Cycle; and 648: Supercontinent Cycles and Global Geodynamics.

\section{References}

Aguilar CPS, Villaseca C (2010) Petrogenesis of highly fractionated I-type peraluminous granites: La Pedriza pluton (Spanish Central System). Geologica Acta 8:131-149

Alcock JE, Martínez Catalán JR, Arenas R, Montes AD (2009) Use of thermal modeling to assess the tectono-metamorphic history of the Lugo and Sanabria gneiss domes, Northwest Iberia. Bulletin de la Société Géologique de France 180:179-197

Alcock JE, Martínez Catalán JR, Rubio Pascual FJ, Díez Montes A, Díez Fernández R, Gómez Barreiro J, Arenas R, Dias da Silva I, González Clavijo E (2015) 2-D thermal modeling of HT-LP metamorphism in NW and Central Iberia: Implications for Variscan magmatism, rheology of the lithosphere and orogenic evolution. Tectonophysics 657:21-37

Antona JF (1991) Fluidos mineralizadores en los yacimientos de oro de Saucelle y El Cabaco (Salamanca), PhD Thesis, Universidad de Salamanca. $236 \mathrm{pp}$

Antona JF, Fallick AE, García Sánchez A (1992) Estudio de isótopos estables en las mineralizaciones de W, As y Au de SaucelleBarruecopardo. NW de Salamanca. Cuadernos del Laboratorio Xeoloxico de Laxe 17:327-340

Arenas R, Martínez Catalán JR (2003) Low-P metamorphism following a Barrovian-type evolution. Complex tectonic controls for a common transition, as deduced in the Mondoñedo thrust sheet (NW Iberian Massif). Tectonophysics 365:143-164

Arenas R, Sánchez Martínez S, Gerdes A, Albert R, Díez Fernández R, Andonaegui P (2014) Re-interpreting the Devonian ophiolites involved in the Variscan suture: $\mathrm{U}-\mathrm{Pb}$ and $\mathrm{Lu}-\mathrm{Hf}$ zircon data of the Moeche Ophiolite (Cabo Ortegal Complex, NW Iberia). Int J Earth Sci 103:1385-1402

Armendáriz M, López-Guijarro R, Quesada C, Pin C, Bellido F (2008) Genesis and evolution of a syn-orogenic basin in transpression: insights from petrography, geochemistry and $\mathrm{Sm}-\mathrm{Nd}$ systematics in the Variscan Pedroches basin (Mississippian, SW Iberia). Tectonophysics 461(1):395-413

Arribas A (1979) Le gisement de tungstène de Barruecopardo. Chron Rech Min 450:42-49

Augier R, Choulet F, Faure M, Turrillot P (2015) A turning-point in the evolution of the Variscan orogen: the ca. 325 Ma regional partial-melting event of the coastal South Armorican domain (South Brittany and Vendée, France). Bulletin de la Société Géologique de France 186(2-3):63-91

Ballèvre M, Martínez Catalán JR, López-Carmona A, Pitra P, Abati J, Díez Fernández R, Ducassou C, Arenas R, Bosse V, Castiñeiras P, Fernández-Suárez J, Gómez Barreiro J, Paquette JL, Peucat JJ, Poujol M, Ruffet G, Sánchez Martínez $S$ (2014) Correlation of the nappe stack in the Ibero-Armorican arc across the Bay of Biscay: a joint French-Spanish project. In: Schulmann K, Martínez Catalán JR, Lardeaux JM, Janoušek V, Oggiano G (eds) The Variscan orogeny: extent, timescale and the formation of the European crust, Geological Society, London, Special Publication no 405, pp 77-113. doi:10.1144/SP405.13

Barbero L (1995) Granulite-facies metamorphism in the Anatectic Complex of Toledo, Spain: late Hercynian evolution by crustal extension. J Geol Soc Lond 152:365-383

Barbero L, Villaseca C (2000) Eclogite facies relics in metabasites from the Sierra de Guadarrama (Spanish Central System): $\mathrm{P}-\mathrm{T}$ estimations and implications for the Hercynian evolution. Mineral Mag 64:815-836

Barbero L, Villaseca C, Rogers G, Brown PE (1995) Geochemical and isotopic disequilibrium in crustal melting: an insight from the anatectic granitoids from Toledo, Spain. J Geophys Res Solid Earth 100:B15745-B15765

Barrière M (1981) On curved laminae, graded layers, convection currents and dynamic crystal sorting in the Ploumanac'h (Brittany) subalkaline granite. Contrib Mineral Petrol 77(3):214-224

Bascones Alvira L, Martín Herrero I, Corretgé Castañón LG (1982) Memoria del Mapa Geológico de España, 1:50000, no 703, Arroyo de la Luz. Instituto Geológico de España, Madrid, 48 pp

Bea F, Montero PG, González-Lodeiro F, Talavera C, Molina JF, Scarrow JH, Whitehouse MJ, Zinger T (2006a) Zircon thermometry and $\mathrm{U}-\mathrm{Pb}$ ion-microprobe dating of the gabbros and associated migmatites of the Variscan Toledo Anatectic Complex, Central Iberia. J Geol Soc 163:847-855

Bea F, Montero PG, Talavera C, Zinger T (2006b) A revised Ordovician age for the Miranda do Douro orthogneiss, Portugal. Zircon U-Pb ion-microprobe and LA-ICPMS dating. Geologica Acta 4:395-401

Bea F, Montero P, Zinger T (2003) The nature, origin, and thermal influence of the granite source layer of Central Iberia. J Geol 111:579-595

Beetsma JJ (1995) The late Proterozoic/Paleozoic and Hercynian crustal evolution of the Iberian Massif, northern Portugal. PhD thesis, Faculty of Earth Sciences, Vrije Universiteit, Amsterdam, $233 \mathrm{pp}$

Boehnke P, Watson EB, Trail D, Harrison TM, Schmitt AK (2013) Zircon saturation re-revisited. Chem Geol 351:324-334

Braid JA, Murphy JB, Quesada C, Bickerton L, Mortensen JK (2012) Probing the composition of unexposed basement, South Portuguese Zone, southern Iberia: implications for the connections between the Appalachian and Variscan orogens. Can J Earth Sci 49(4):591-613

Brown M (2001) Orogeny, migmatites and leucogranites: a review. J Earth Syst Sci 110:313-336

Brown M (1994) The generation, segregation, ascent and emplacement of granite magma: the migmatite-to-crustally-derived granite connection in thickened orogens. Earth Sci Rev $36: 83-130$

Cambeses A, Scarrow JH, Montero P, Molina JF, Moreno JA (2015) SHRIMP U-Pb zircon dating of the Valencia del Ventoso plutonic complex, Ossa-Morena Zone, SW Iberia: early Carboniferous intra-orogenic extension-related 'calcalkaline'magmatism. Gondwana Res 28:735-756

Capdevila R, Corretgé LG, Floor P (1973) Les granitoïdes de la Meseta Ibérique. Bulletin de la Société Géologique de France, XV 3-4:209-228

Castiñeiras P, Villaseca C, Barbero L, Martín Romera C (2008) SHRIMP U-Pb zircon dating of anatexis in high-grade migmatite complexes of Central Spain: implications in the Hercynian evolution of Central Iberia. Int J Earth Sci 97:35-50

Castro A, Corretgé LG, El-Biad M, El-Hmidi H, Fernández C, Douce AEP (2000) Experimental constraints on Hercynian anatexis in the Iberian Massif, Spain. J Petrol 41:1471-1488 
Castro A, Patiño Douce AE, Corretgé LG, De la Rosa JD, El-Biad M, El-Hmidi H (1999) Origin of peraluminous granites and granodiorites, Iberian massif, Spain: an experimental test of granite petrogenesis. Contrib Miner Petrol 135:255-276

Castro A, Moreno-Ventas I, De La Rosa JD (1991) H-type (hybrid) granitoids: a proposed revision of the granite-type classification and nomenclature. Earth Sci Rev 31:237-253

Castro A, Corretgé LG, De la Rosa JD, Enrique P, Martínez FJ, Pascual E, Lago M, Arranz E, Galé C, Fernández C, Donaire T, López S (2002) Palaeozoic Magmatism. In: Moreno T, Gibbons W (eds) The Geology of Spain. Geological Society, London, pp $117-153$

Chappell BW, Stephens WE (1988) Origin of infracrustal (I-type) granite magmas. Trans R Soc Edinburgh Earth Sci 79:71-86

Costa MM, Neiva AMR, Azevedo MR, Corfu F (2014) Distinct sources for syntectonic Variscan granitoids: Insights from the Aguiar da Beira region, Central Portugal. Lithos 196:83-98

Dallmeyer RD, García-Casquero JL, Quesada C (1995) 40Ar/39Ar Mineral age constraints on the emplacement of the Burguillos del Cerro Igneous complex (Ossa-Morena zone, SW Iberia). Boletín Geológico y Minero 106:3-14

Dias G, Leterrier J, Mendes A, Simões PP, Bertrand JM (1998) U-Pb zircon and monazite geochronology of post-collisional Hercynian granitoids from the Central Iberian Zone (Northern Portugal). Lithos 45(1):349-369

Díez Fernández R, Martínez Catalán JR, Gómez Barreiro J, Arenas R (2012) Extensional flow during gravitational collapse: a tool for setting plate convergence (Padrón migmatitic dome, Variscan belt, NW Iberia). J Geol 120:83-103

Díez Fernández R, Pereira MF (2017) Extensional orogenic collapse captured by strike-slip tectonics: Constraints from structural geology and U-Pb geochronology of the Pinhel shear zone (Variscan orogen, Iberian Massif). Tectonophysics. doi:10.1016/j.tecto.2016.10.023

Díez Montes, A (2007) La geología del dominio "Ollo de Sapo" en las Comarcas de Sanabria y Terra de Bolo. Nova Terra, 34 Instituto Universitario de Geología, Universidad de La Coruña, 494 $\mathrm{pp}$

Díez Montes A, Escuder Viruete J, Carrasco RM, Sanz Santos MA (1991) Mapa Geológico Nacional, Escala 1:50000, Hoja de Vilvestre (448-449). I.G.M.E, Madrid, 159 pp

Díez Montes A, Martínez Catalán JM, Mulas FB (2010) Role of the Ollo de Sapo massive felsic volcanism of NW Iberia in the Early Ordovician dynamics of northern Gondwana. Gondwana Res 17(2):363-376

Dupuis NE, Braid JA, Murphy JB, Quesada C, McFarlane C (2014) Changing mantle sources in a suture zone in the heart of Pangea: implications for collisional tectonics during the waning stages of ocean closure. Int J Earth Sci 103:1403-1414

Escuder Viruete J (1998) Relationships between structural units in the Tormes gneiss dome (NW Iberian massif, Spain): geometry, structure and kinematics of contractional and extensional Variscan deformation. Geol Rundsch 87:165-179

Escuder Viruete J, Arenas R, Martínez Catalán JR (1994) Tectonothermal evolution associated with Variscan crustal extension in the Tormes gneiss dome (NW Salamanca, Iberian Massif, Spain). Tectonophysics 238:117-138

Escuder Viruete J, Hernáiz Huerta P, Valverde-Vaquero P, Fernández LR, Dunning G (1998) Variscan syncollisional extension in the Iberian Massif: structural, metamorphic and geochronological evidence from the Somosierra sector of the Sierra de Guadarrama (Central Iberian Zone, Spain). Tectonophysics 290:87-109

Escuder Viruete J, Indares A, Arenas R (1997) P-T path determinations in the Tormes Gneissic Dome, NW Iberian Massif, Spain. J Metamorph Geol 15:645-663
Escuder Viruete J, Indares A, Arenas R (2000) P-T paths derived from garnet growth zoning in an extensional setting: an example from the Tormes Gneissic Dome (Iberian Massif, Spain). J Petrol 41:1488-1518

Faure M, Mézème E, Cocherie A, Melleton J, Rossi P (2009a) The South Millevaches Middle Carboniferous crustal melting and its place in the French Variscan belt. Bulletin de la Société Géologique de France 180:473-481

Faure M, Lardeaux JM, Ledru P (2009b) A review of the pre-Permian geology of the Variscan French Massif Central. Comptes Rendus Géosci 341:202-213

Fernández-Lozano J, Pastor-Galán D, Gutiérrez-Alonso G, Franco P (2016) New kinematic constraints on the Cantabrian orocline: a paleomagnetic study from the Peñalba and Truchas synclines, NW Spain. Tectonophysics 681:195-208. doi:10.1016/j.tecto.2016.02.019

Fernández-Suárez J, Arenas R, Abati J, Martínez Catalán JR, Whitehouse MJ, Jeffries TE (2007) U-Pb chronometry of polymetamorphic high-pressure granulites: an example from the allochthonous terranes of the NW Iberian Variscan belt. In: Hatcher RDJr, Carlson MP, McBride JH, Martínez Catalán JR (eds) 4-D framework of continental crust, vol 200. Geological Society of America Memoir, Boulder (USA), pp 469-488

Fernández-Suárez J, Gutiérrez-Alonso G, Jenner GA, Jackson SE (1998) Geochronology and geochemistry of the Pola de Allande granitoids (northern Spain): their bearing on the Cadomian-Avalonian evolution of northwest Iberia. Can J Earth Sci 35(12):1439-1453

Fernández-Suárez J, Dunning GR, Jenner GA, Gutiérrez-Alonso G (2000) Variscan collisional magmatism and deformation in NW Iberia: constraints from U-Pb geochronology of granitoids. J Geol Soc 157(3):565-576

Fernández-Suárez J, Gutiérrez-Alonso G, Johnston ST, Jeffries TE, Pastor-Galán D, Jenner GA, Murphy JB (2011) Iberian lateVariscan granitoids: some considerations on crustal sources and the significance of "mantle extraction ages". Lithos 123:121-132

Fernández-Suárez J, Gutiérrez-Alonso G, Pastor-Galán D, Hofmann M, Murphy JB, Linnemann U (2014) The EdiacaranEarly Cambrian detrital zircon record of NW Iberia: possible sources and paleogeographic constraints. Int J Earth Sci 103:1335-1357

Ferreira N, Castro P, Pereira E, Dias G, Miranda A (2000) Syntectonic plutonism and Variscan anatexis of a Cadomian crust (Miranda do Douro region). In: Dias G, Noronha F, Ferreira $\mathrm{N}$ (eds) Variscan plutonism in the Central Iberian Zone (Northern Portugal). Eurogranites 2000, Guide Book (2000), pp $155-172$

Frei D, Gerdes A (2009) Precise and accurate in situ U-Pb dating of zircon with high sample throughput by automated LA-SF-ICPMS. Chem Geol 261:261-270

Galán G, Corretgé LG, Laurent O (1997) Low-potassium vaugnerites from Guéret (Massif Central, France). Mafic magma evolution influenced by contemporaneous granitoids. Mineral Petrolol 59:165-187

Gallastegui G (2005) Petrología del macizo granodiorítico de BayoVigo (Provincia de Pontevedra, España). Serie Nova Terra, 26. Laboratorio Xeoloxico de Laxe. Área de Xeoloxía e Minería do Seminario de Estudos Galegos. Ediciós O Castro, La Coruña, p 414

García-Arias M, Corretgé LG (2010) Thermodynamic models and experimental petrology: the case of the anhydrous melting of the Ollo de Sapo gneiss. Estud Geol 66:57-64

Gil Ibarguchi JI, Martínez FJ (1982) Petrology of garnet-cordierite-sillimanite gneisses from the El Tormes thermal dome, 
Iberian Hercynian foldbelt (W Spain). Contrib Miner Petrol 80:14-24

Gladney ER, Braid JA, Murphy JB, Quesada C, McFarlane CR (2014) $\mathrm{U}-\mathrm{Pb}$ geochronology and petrology of the late Paleozoic Gil Márquez pluton: magmatism in the Variscan suture zone, southern Iberia, during continental collision and the amalgamation of Pangea. Int J Earth Sci 103:1433-1451

Gloaguen E (2006) Apports d'une étude intégrée sur les relations entre granites et minéralisations filoniennes (Au et $\mathrm{Sn}-\mathrm{W})$ en contexte tardiorogénique (Chaîne Hercynienne, Galice centrale, Espagne). $\mathrm{PhD}$ thesis, Université d'Orléans, p 575

Gloaguen E, Ruffet G, Monié P, Barbanson L, Branquet Y, Chauvet A, Bouchot V (2006) Geochronological constraints on the magmatic and hydrothermal evolution of the Tras-os-Montes Hercynian domain (Galica, Spain): position of the Au, Sn-W mineralizing events. In: Colloque Transmet, 2006, France. SFMC, pp 111-114, 2006, 06-07 July 2006-Nancy

Gomes MEP, Teixeira RJS, Neiva AMR, Corfu F (2014) Geoquímica e geocronologia dos granitóides da região de Bemposta-Picote, Nordeste de Portugal. Comunicações Geológicas, 101, Especial I, pp 115-118. http://www.lneg.pt/iedt/unidades/16/ paginas/26/30/185

Gutiérrez-Alonso G, Collins AS, Fernández-Suárez J, Pastor-Galán D, González-Clavijo E, Jourdan F, Weil AB, Johnston ST (2015) Dating of lithospheric buckling: ${ }^{40} \mathrm{Ar} /{ }^{39} \mathrm{Ar}$ ages of syn-orocline strike-slip shear zones in northwestern Iberia. Tectonophysics 643:44-54

Gutiérrez-Alonso G, Murphy JB, Fernández-Suárez J, Hamilton MA (2008) Rifting along the northern Gondwana margin and the evolution of the Rheic Ocean: a Devonian age for the El Castillo volcanic rocks (Salamanca, Central Iberian Zone). Tectonophysics 461:157-165

Gutiérrez-Alonso G, Fernández-Suárez J, Jeffries TE, Johnston ST, Pastor-Galán D, Murphy JB, Franco MP, Gonzalo JC (2011) Diachronous post-orogenic magmatism within a developing orocline in Iberia, European Variscides. Tectonics. doi:10.1029 /2010TC002845

Hall CM, Higueras PL, Kesler SE, Lunar R, Dong H, Halliday AN (1997) Dating of alteration episodes related to mercury mineralization in the Almadén district, Spain. Earth Planet Sci Lett 148:287-298

Hernández A, Jébrak M, Higueras P, Oyarzun R, Morata D, Munhá J (1999) The Almadén mercury mining district, Spain. Miner Deposita 34:539-548

Holtz F, Barbey P (1991) Genesis of peraluminous granites II. Mineralogy and chemistry of the Tourem Complex (North Portugal). Sequential melting vs. restite unmixing. J Petrol 32:959-978

Iglesias M, Choukroune P (1980) Shear zones in the Iberian Arc. J Struct Geol 2(1-2):63-68

Jesus AP, Munhá J, Mateus A, Tassinari C, Nutman AP (2007) The Beja layered gabbroic sequence (Ossa-Morena Zone, Southern Portugal): geochronology and geodynamic implications. Geodin Acta 20:139-157

Kroner U, Romer RL (2013) Two plates-many subduction zones: the Variscan orogeny reconsidered. Gondwana Res 24:298-329

Kroner U, Roscher M, Romer RL (2016) Ancient plate kinematics derived from the deformation pattern of continental crust: Paleo- and Neo-Tethys opening coeval with prolonged Gondwana-Laurussia convergence. Tectonophysics 681:220-233

Lardeaux JM, Schulmann K, Faure M, Janoušek V, Lexa O, Skrzypek E, Edel JB, Stipska P (2014) The Moldanubian Zone in the French Massif Central, Vosges/Schwarzwald and Bohemian Massif revisited: differences and similarities. In: Schulmann K, Martínez Catalán JR, Lardeaux JM, Janoušek V, Oggiano G (eds) The Variscan orogeny: extent, timescale and the formation of the European crust. Geological Society, London, Special Publications, 405, pp 7-44

Ledru P, Courrioux G, Dallain C, Lardeaux J-M, Montel J-M, Vanderhaeghe O, Vitel G (2001) The Velay dome (French Massif Central): melt generation and granite emplacement during orogenic evolution. Tectonophysics 342:207-237

Li XH, Faure M, Lin W (2014) From crustal anatexis to mantle melting in the Variscan orogen of Corsica (France): SIMS U-Pb zircon age constraints. Tectonophysics 634:19-30

Loeschke J (1983) Igneous and pyroclastic rocks in Devonian and Lower Carboniferous strata of the Cantabrian Mountains (NW Spain). Neues Jahrbuch für Geologie und Paläontologie. Abhandlungen 7:419-439

López-Moro FJ, López-Plaza M (2004) Monzonitic series from the Variscan Tormes Dome (Central Iberian Zone): petrogenetic evolution from monzogabbro to granite magmas. Lithos 72:19-44

López-Moro FJ, Murciego A, López-Plaza M (2007) Silurian/Ordovician asymmetrical sill-like bodies from La Codosera syncline, W Spain: A case of tholeiitic partial melts emplaced in a single magma pulse and derived from a metasomatized mantle source. Lithos 96:567-590

López-Moro FJ, López-Plaza M, Romer RL (2012) Generation and emplacement of shear-related highly mobile crustal melts: the synkinematic leucogranites from the Variscan Tormes Dome, Western Spain. Int J Earth Sci 101:1273-1298

López-Plaza M (1980) Comportamiento reológico, fuerza ascensional y deformación en el material granítico: Aplicación al plutón de Ledesma (Salamanca). Boletín Geológico y Minero XCI:649-666

López-Plaza M (1982) Contribución al conocimiento de la dinámica de los cuerpos graníticos en la penillanura salmantino-zamorana. $\mathrm{PhD}$ Thesis, Universidad de Salamanca, $333 \mathrm{pp}$

López-Plaza M, Gonzalo J (1993) Caracterización geoquímica de las anatexitas del Domo del Tormes (provincias de Salamanca y Zamora). Rev Soc Geol España 6:3-4

López-Plaza M, López-Moro FJ (2008) The Tormes Dome. In: LópezPlaza M, López-Moro FJ (eds) Eurogranites in Western Castilla y León, part II. University of Salamanca, Salamanca, pp 1-192

López-Plaza M, López-Moro FJ, Gonzalo Corral JC, Carnicero A (1999) Asociaciones de rocas plutonicas básicas e intermedias de afinidad calcoalcalina y shoshonítica y granitoides relacionados en el Domo Hercínico del Tormes (Salamanca y Zamora). Boletín de la Sociedad Española de Mineralogía 22:211-234

López-Plaza M, López-Moro FJ (2004) El Domo del Tormes. In: Vera JA (ed) Geología de España. SGE-IGME, Madrid, pp 100-101

López-Plaza M, López-Moro FJ, Vicente-Tavera A, Vicente-Villardón JL (2008) Los leucogranitos equigranulares del Domo del Tormes (Zona Centro Ibérica): discriminación geoquímica mediante Biplot Canónico y significado petrogenético. E-Terra, 5. http://e-terra.geopor.pt/eng/index_en1.html

Ludwig KR (2012) Isoplot/Ex, v. 3.75, vol 5. Berkeley Geochronology Center Special Publication, Berkeley (USA), 75 pp

Martínez Catalán JR, González Clavijo E, Meireles C, Díez Fernández R, Bevis J (2016) Relationships between syn-orogenic sedimentation and nappe emplacement in the hinterland of the Variscan belt in NW Iberia deduced from detrital zircons. Geol Mag 153:38-60

Martínez Catalán JR, Rubio Pascual FJ, Díez Montes A, Díez Fernández R, Gómez Barreiro J, Dias da Silva Í, González Clavijo E, Ayarza P, Alcock JE (2014) The late Variscan HT/LP metamorphic event in NW and Central Iberia: relationships to crustal thickening, extension, orocline development and crustal evolution. In: Schulmann K, Martínez Catalán JR, Lardeaux JM, Janoušek V, Oggiano G (eds) The Variscan orogeny: extent, 
timescale and the formation of the European crust. Geological Society, London, Special Publications, 405, pp 225-247

Martínez FJ (1977) Données sur le métamorphisme regional hercynien dans le dôme du Tormes. Geol. Rudschau 66:91-98

Martínez FJ, Rolet J (1988) Late Palaeozoic metamorphism in the northwestern Iberian Peninsula, Brittany and related areas in SW Europe. In: Harris AL, Fettes DJ (eds) The caledonianappalachian orogen. Geological Society, London, Special Publications, 38, pp 611-620

Martínez FJ, Julivert M, Sebastian A, Arboleya ML, Gil Ibarguchi I (1988) Structural and thermal evolution of high grade areas in the northwestern parts of the Iberian Massif. Am J Sci 288:969-996

Mateus A, Munhá J, Ribeiro A, Tassinari CCG, Sato K, Pereira E, Santos JF (2016) U-Pb SHRIMP zircon dating of high-grade rocks from the Upper Allochthonous Terrane of Bragança and Morais Massifs (NE Portugal); geodynamic consequences. Tectonophysics. doi:10.1016/j.tecto.2016.02.048

Matte P (1986) Tectonics and plate tectonics model for the Variscan belt of Europe. Tectonophysics 126:329-374

Matte P (2001) The Variscan collage and orogeny (480 $\pm 290 \mathrm{Ma})$ and the tectonic definition of the Armorica microplate: a review. Terra Nova 13:122-128

Merino-Tomé O, Gutiérrez-Alonso G, Villa E, Fernández-Suárez J, Martín Llaneza J, Hofmann M (in press) LA-ICP-MS U-Pb dating of Carboniferous ash layers in the Cantabrian Zone $(\mathrm{N}$ Spain): stratigraphic implications. J Geol Soc. doi:10.1144/ jgs2016-119merino-tom

Mezger JE, Gerdes A (2016) Early Variscan (Visean) granites in the core of central Pyrenean gneiss domes: implications from laser ablation U-Pb and Th-Pb studies. Gondwana Res 29:181-198

Montero P, Bea F, González-Lodeiro F, Talavera C, Whitehouse MJ (2007) Zircon ages of the metavolcanic rocks and metagranites of the Ollo de Sapo Domain in central Spain: implications for the Neoproterozoic to Early Palaeozoic evolution of Iberia. Geol Mag 144:963-976

Montero P, Salman K, Bea F, Azor A, Expósito I, González Lodeiro F, Poyatos D, Simancas F (2000) New data on the geochronology of the Ossa-Morena Zone, Iberian Massif. Basement Tecton 15:136-138

Murphy JB, Gutiérrez-Alonso G, Nance RD, Fernández-Suárez J, Keppie JD, Quesada C, Strachan RA, Dostal J (2006) Origin of the Rheic ocean: rifting along a neoproterozoic suture? Geology 34(5):325-328

Murphy JB, Gutiérrez-Alonso G, Fernández-Suárez J, Braid JA (2008) Probing crustal and mantle lithosphere origin through Ordovician volcanic rocks along the Iberian passive margin of Gondwana. Tectonophysics 461:166-180

Murphy JB, Nance RD, Cawood PA (2009) Contrasting modes of supercontinent formation and the conundrum of Pangea. Gondwana Res 15:408-420

Nachit H, Razafimahefa N, Stussi JM, Carron JP (1985) Composition chimique des biotites et typologie magmatique des granitoides. Comptes rendus de l'Académie des sciences. Série 2, Mécanique, Physique, Chimie, Sciences de l'Univers. Sciences de la Terre 301(11):813-818

Naslund HR, McBirney AR (1996) Mechanisms of formation of igneous layering. Dev Petrol 15:1-43

Ordóñez Casado B (1998) Geochronological studies of the Pre-Mesozoic basement of the Iberian Massif: the Ossa Morena zone and the Allochthonous Complexes within the Central Iberian zone. $\mathrm{PhD}$ Thesis, ETH, Zurich, $235 \mathrm{pp}$

Ordóñez Casado B, Martín-Izard A, García-Nieto J (2008) SHRIMPzircon $\mathrm{U}-\mathrm{Pb}$ dating of the Ni-Cu-PGE mineralized Aguablanca gabbro and Santa Olalla granodiorite: confirmation of an Early
Carboniferous metallogenic epoch in the Variscan Massif of the Iberian Peninsula. Ore Geol Rev 34:343-353

Orejana D, Villaseca C, Pérez-Soba C, López-García JA, Billström K (2009) The Variscan gabbros from the Spanish Central System: a case for crustal recycling in the sub-continental lithospheric mantle? Lithos 110(1):262-276

Passchier CW, Trouw RAJ (2005) Microtectonics. Springer, Berlin

Pastor-Galán D, Gutiérrez-Alonso G, Murphy JB, Fernández-Suárez J, Hofmann M, Linnemann U (2013) Provenance analysis of the Paleozoic sequences of the northern Gondwana margin in NW Iberia: passive margin to Variscan collision and orocline development. Gondwana Res 23:1089-1103

Pastor-Galán D, Dekkers MJ, Gutiérrez-Alonso G, Brower D, Groenewegen T, Krigsman W, Fernández-Lozano J, Yenes M, Álvarez-Lobato F (2016) Paleomagnetism of the Central Iberian curve's putative hinge: Too many oroclines in the Iberian Variscides. Gondwana Res 39:96-113

Pellitero E, Saavedra J, García-Sánchez A, Arribas A (1976) Geoquímica del $\mathrm{W}$ en el área circundante al yacimiento de cheelita de Barruecopardo (Salamanca). Acta geológica hispánica 11(5):133-136

Pereira MF, Chichorro M, Moita P, Santos JF, Solá AMR, Williams IS, Silva JB, Armstrong RA (2015) The multistage crystallization of zircon in calc-alkaline granitoids: U-Pb age constraints on the timing of Variscan tectonic activity in SW Iberia. Int J Earth Sci 104:1167-1183

Pereira MF, Chichorro M, Williams IS, Silva JB, Fernández C, DíazAzpiroz M, Apraiz A, Castro A (2009) Variscan intra-orogenic extensional tectonics in the Ossa-Morena Zone (Évora-AracenaLora del Río metamorphic belt, SW Iberian Massif): SHRIMP zircon U-Th-Pb geochronology. In: Murphy JB, Keppie JD, Hynes AJ (eds) Ancient orogens and modern analogues. Geological Society, London, Special Publications, 327, pp 215-237

Pin C, Fonseca PE, Paquette JL, Castro P, Matte P (2008) The ca. 350 Ma Beja Igneous Complex: a record of transcurrent slab break-off in the Southern Iberia Variscan Belt? Tectonophysics 461:356-377

Pin C, Paquette JL, Ábalos B, Santos Zalduegui JF, Gil Ibarguchi JI (2006) Composite origin of an early Variscan transported suture: ophiolitic units of the Morais Nappe Complex (north Portugal). Tectonics 25:TC5001. doi:10.1029/2006TC001971

Pitcher WS (1993) The nature and origin of granite. Blackie Academic and Professional, London, Glasgow, p 321

Reche J, Martínez FJ, Arboleya ML, Dietsch C, Briggs WD (1998) Evolution of a kyanite-bearing belt within a HT-LP orogen: the case of NW Variscan Iberia. J Metamorph Geol 16:379-394

Roberts MP, Clemens JD (1993) Origin of high-potassium, calc-alkaline, I-type granitoids. Geology 21:825-828

Rodríguez-Alonso MD, Peinado M, López-Plaza M, Franco P, Carnicero A, Gonzalo JC (2004) Neoproterozoic-Cambian synsedimentary magmatism in the Central Iberian Zone (Spain): geology, petrology and geodynamic significance. Int J Earth Sci 93:897-920

Romeo I, Lunar R, Capote R, Quesada C, Dunning GR, Piña R, Ortega L (2006) U-Pb age constraints on Variscan magmatism and Ni-Cu-PGE metallogeny in the Ossa-Morena Zone (SW Iberia). J Geol Soc 163:837-846

Rossi P, Cocherie A (1991) Genesis of a Variscan batholith: field, petrological and mineralogical evidence from the Corsica-Sardinia Batholith. Tectonophysics 195:319-346

Rubio-Ordóñez A, Gutiérrez-Alonso G, Valverde-Vaquero P, Cuesta A, Gallastegui G, Gerdes A, Cárdenes V (2015) Arc-related Ediacaran magmatism along the northern margin of Gondwana: Geochronology and isotopic geochemistry from northern Iberia. Gondwana Res 27(1):216-227 
Rubio Pascual FJ, Arenas R, Martínez Catalán JR, Rodríguez Fernández LR, Wijbrans JR (2013) Thickening and exhumation of the Variscan roots in the Iberian Central System: Tectonothermal processes and $40 \mathrm{Ar} / 39 \mathrm{Ar}$ ages. Tectonophysics 587:207-221

Sánchez Martínez S, Arenas R, Gerdes A, Castiñeiras P, Potrel A, Fernández-Suárez J (2011) Isotope geochemistry and revised geochronology of the Purrido Ophiolite (Cabo Ortegal Complex, NW Iberian Massif): devonian magmatism with mixed sources and involved Mesoproterozoic basement. J Geol Soc Lond 168:733-750

Sanderson DJ, Roberts S, Gumiel P, Greenfield C (2008) Quantitative analysis of tin-and tungsten-bearing sheeted vein systems. Econ Geol 103(5):1043-1056

Sawyer EW (1994) Melt segregation in the continental crust. Geology 22:1019-1022

Sawyer EW (1999) Criteria for the recognition of partial-melting. Phys Chem Earth Part A Solid Earth Geodesy 24:269-279

Soldevila Bartolí J (1992) La sucesión paleozoica en el sinforme de la Sierra de San Pedro (provincias de Cáceres y Badajoz, SO de España). Estud Geol 48:363-379

Stacey JT, Kramers JD (1975) Approximation of terrestrial lead isotope evolution by a two-stage model. Earth Planet Sci Lett 26:207-221

Tabaud AS, Janoušek V, Skrzypek E, Schulmann K, Rossi P, Whitechurch H, Guerrot C, Paquette JL (2015) Chronology, petrogenesis and heat sources for successive Carboniferous magmatic events in the Southern-Central Variscan Vosges Mts (NE France). J Geol Soc 172:87-102

Talavera C, Montero P, Bea F, González Lodeiro F, Whitehouse M (2013) U-Pb zircon geochronology of the Cambro-Ordovician metagranites and metavolcanic rocks of central and NW Iberia. Int J Earth Sci 102:1-23
Timmerman MJ (2008) Palaeozoic magmatism. In: McCann T (ed) The geology of Central Europe, vol 1., Precambrian and PalaeozoicGeological Society, London, pp 665-748

Valle Aguado B, Azevedo MR, Schaltegger U, Martínez Catalán JR, Nolan J (2005) U-Pb zircon and monacite geochronology of Variscan magmatism related to syn-convergence extension in Central northern Portugal. Lithos 82:169-184

Valverde-Vaquero P, Dunning GR (2000) New U-Pb ages for Early Ordovician magmatism in central Spain. J Geol Soc 157(1):15-26

Valverde-Vaquero P, Díez Balda MA, Díez Montes A, Dörr W, Escuder Viruete J, González C, Maluski H, Rodríguez Fernández LR, Rubio F, Villar P (2007) The "hot orogen": two separate Variscan low-pressure metamorphic events in the Central Iberian Zone. In: Faure M, Lardeaux J-M, Ledru P, Peschler A, Schulmann K (eds) Mechanics of Variscan Orogeny: a modern view on orogenic research. Géologie de la France 2007, 2. Société Géologique de France and Bureau de Recherches Géologiques et Minières, Paris, 168

Vanderhaeghe O (2004) Structural development of the Naxos migmatite dome. In: Whitney D, Teyssier C, Siddoway CS (eds) Gneiss domes in orogeny. Geological Society of America, Boulder (USA), Special Paper, 380, pp 211-228

Vanderhaeghe O, Teyssier C (2001) Partial-melting and flow of orogens. Tectonophysics 342:451-472

Villa IM, De Brièvre P, Holden NE, Renne PR (2015) IUPAC-IUGS recomendation oh the half life of $87 \mathrm{Rb}$. Geochim Cosmochim Acta 164:382-385

von Raumer JF, Finger F, Veselá P, Stampfli GM (2014) DurbachitesVaugnerites-a geodynamic marker in the central European Variscan orogen. Terra Nova 26:85-95 